\title{
Geomechanics of Australian open cut coal mining
}

\author{
JV Simmons Sherwood Geotechnical and Research Services, and The University of Newcastle, Australia
}

\begin{abstract}
Australian black coal and brown coal mining is an important contributor to the Australian economy. The intent of this paper is to provide concise reference information to geotechnical practitioners. Geology of coals, coal measures rocks, overburdens, and groundwater are described. Mining operations for the black coal and brown coal industries are very different. Both are outlined to provide a context for geotechnical characterisation that covers rank, coal materials, virgin and pre-existing stress states, and data gathering. Geotechnical models and parameters are described separately for the black coal and brown coal sectors. Information is provided regarding material and mass strength, deformability, degradation and weathering, hydraulic conductivity, gas desorption and outburst, and waste dumping. An overview of analytical tools is provided for defect mapping, slope stability, and deformation and groundwater pressure modelling. Discussion of geotechnical aspects of final post-mining landforms is also provided.
\end{abstract}

Keywords: open cut coal mining, shear strength, extension, deformability, hydraulic conductivity, subsidence

\section{Introduction}

Coal mining plays a significant role in Australia's economy. Until recently, coal has dominated the supply of energy to Australian lives and industries, and it is still the major contributor. Australian black coal has also played a significant role in developing and sustaining the economies of other nations. In the writer's working lifetime, Australian black coal mining has expanded from little more than meeting domestic power generation requirements to becoming the dominant supplier to the world's seaborne coal trade. Australian brown coal mining has a long history of production to meet domestic power generation requirements. Both sectors have required significant geotechnical contributions to the development and support of cost-effective and large-scale safe mining practices.

There is a simple reason why this paper is focused on the geomechanics of Australian open cut coal mining. Coal measures rocks and related geological conditions have been regarded as 'weak rocks' by the large open pit mining community responsible for development of the range of guidelines texts with which we are familiar. The weak rocks guidelines (Martin \& Stacey 2018) include very limited information about materials and geological conditions that are directly relevant to the Australian open cut coal mining geotechnical community. Prior information relevant to black coal mining (Simmons 2013) requires updating. While there is a large body of information regarding brown coal mining, it is not widely accessible. This paper is intended to address these information gaps, both locally and in the context of knowledge and practice that may be valuable worldwide.

Locations of Australian coal resources and mines are outlined in Figure 1. A map of Australian surficial geology (Raymond 2012) shows that the coal resources largely exist under a cover of materials other than coal measures rocks. Open cut mining accounts for about $60 \%$ of black coal production. Knowledge of black coal geology and geomechanics is based as much on investigations for underground as for open cut mining purposes, predominantly but not entirely from Queensland and New South Wales coalfields. Arguably, geomechanics knowledge for brown coal was established earlier and more comprehensively than for black coal, during the formative years of large-scale open cut mining of lignite-dominated basins in Victoria.

Subdivisions between the Australian brown coal and black coal sectors are dominated by geographical and market considerations as much as by geological and geotechnical differences. These differences have become profound enough that there is little technical interaction between the two sectors. This paper addresses both 
sectors. It is focused on slope engineering considerations that are different primarily because of geological and geotechnical conditions.

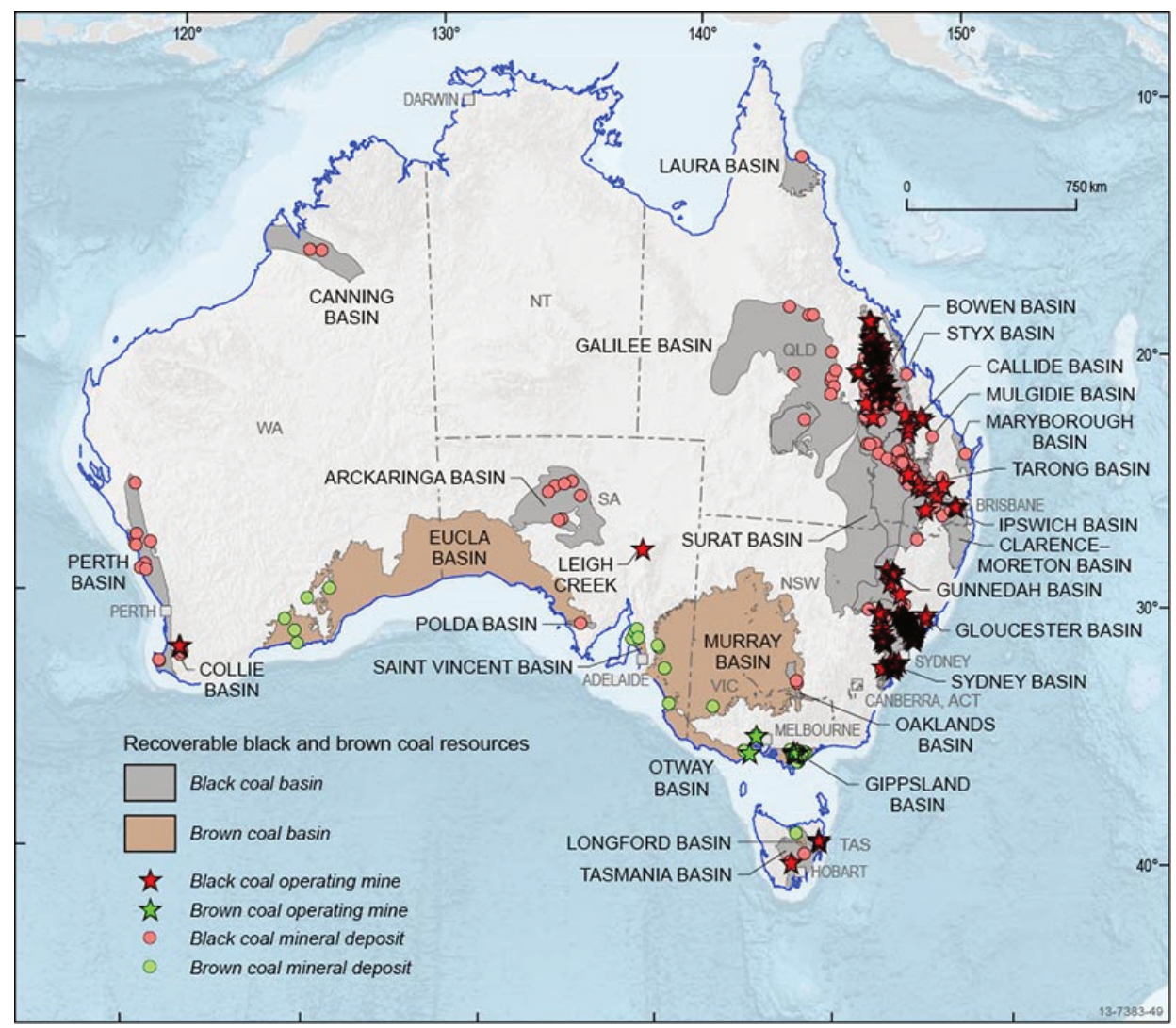

Figure 1 Australian Coal Resources Map 2013 (Geoscience Australia 2013)

\section{Geology}

\subsection{Coal materials}

Coal is a broad term for a spectrum of carbon-rich rock or rock-like materials. In the same way that 'sedimentary rock' describes a vast range of mineral particles and binding agents, 'coal' describes a vast range of organic and mineral components linked by complex organic bonds. Geologists habitually describe coal in terms of rank: economically significant Australian coals (Standards Australia 1987) range in rank from 'brown coal' (lignite) to 'black coal' (sub-bituminous to semi-anthracite). Geotechnical practitioners should describe coal in terms of physically observable characteristics (Standards Australia 2017) such as strength (extremely low to high) and appearance (intact and homogeneous to highly structured and anisotropic). All such descriptions can be simplistic but are useful starting points for appreciating the linkages between geological and geomechanical viewpoints of material and mass behaviour.

Coal forms from the accumulation of organic material under certain conditions that result in self-compacting anaerobic peat swamps. Sedimentary basins that accumulate economic coal deposits are crustal-scale events driven by tectonic or thermal processes where the basin subsidence rate must fall within a range constrained by the balance between consumption and preservation of organic materials. At small-scale, the accumulation of organic matter comprises both fibrous and gel components together with distributary channels that transmit water and sediment. Peat originates in both estuarine and alluvial environments, both of which may incorporate iron-rich sulphides. It should be expected that coal seams of economic significance, while appearing to be predictable at mine-scale, may be locally variable enough to trigger resource recovery, geomechanical, and environmental issues that can only be identified in detail during mining activities. 


\section{$2.2 \quad$ Coal measures rocks}

Australian coals are widely distributed (Figure 1) but the most economically significant are found where large-scale sedimentary basins were active for long periods during suitable global climate and vegetation regimes:

- Sydney - Gunnedah - Bowen Basins: formed during the Carboniferous and reaching maximum development in the Late Permian, and the principal location of black coal mining.

- Clarence-Moreton and Surat Basins: formed as a Jurassic component of the Great Artesian Basin, a subsidiary location of black coal and a major location for coal seam gas extraction.

- Gippsland - Otway Basins: formed during the Palaeogene and Neogene, and the principal location of lignite mining for power generation in Victoria.

Permian sedimentary basins formed adjacent to the coast of what was then Gondwana (Sirevaag et al. 2018), with an active subduction zone to what is now the east and marginal volcanic arcs supplying the majority of the lithic sediments. Alluvial and estuarine plains with distributary channels controlled the distribution of swamps and non-coal sediments, forming coals interbedded with siltstones and sandstones. The end-Permian mass extinction event resulted in a gap in coal formation but continuation of sedimentary basin development. More localised coal basins developed later in the Triassic. Broader-scale but generally lower-rank coals subsequently developed during the Jurassic in alluvial floodplain basins that somewhat overly the earlier Permian basins, forming thicker coals interbedded with claystones, siltstones, and sandstones.

Palaeogene-Neogene sedimentary basins formed along the south and southeast Australian margins during extensional rifting as the continent separated from Antarctica during the final breakup of Gondwana. The Gippsland Basin (Figure 2) developed in both terrestrial and marine settings with an intermediate beach-barrier zone that now separates remarkably thick lignite resources from offshore petroleum resources: both are of great economic significance. Figure 3 is an isopach map of one of the most economically significant lignite seams-exceeding $100 \mathrm{~m}$ thickness-of the Latrobe Valley depression. Despite such great thicknesses, the Latrobe Valley deposits preserve typical lateral and vertical variability (Figure 4) associated with alluvial floodplains close to beach-barrier sand complexes.

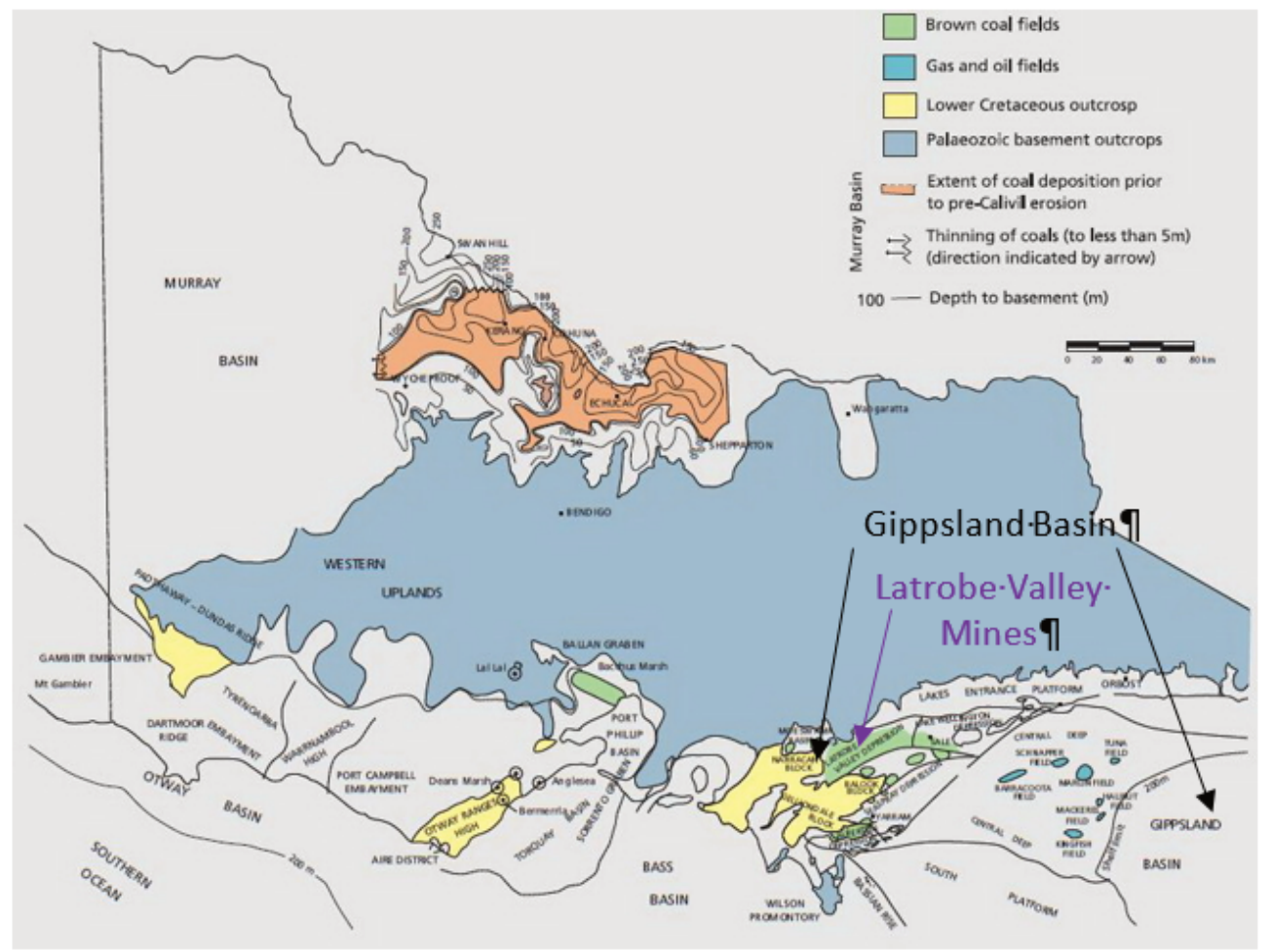

Figure 2 Victorian coal basins showing location of Latrobe Valley brown coal deposits (Holdgate 2003) 


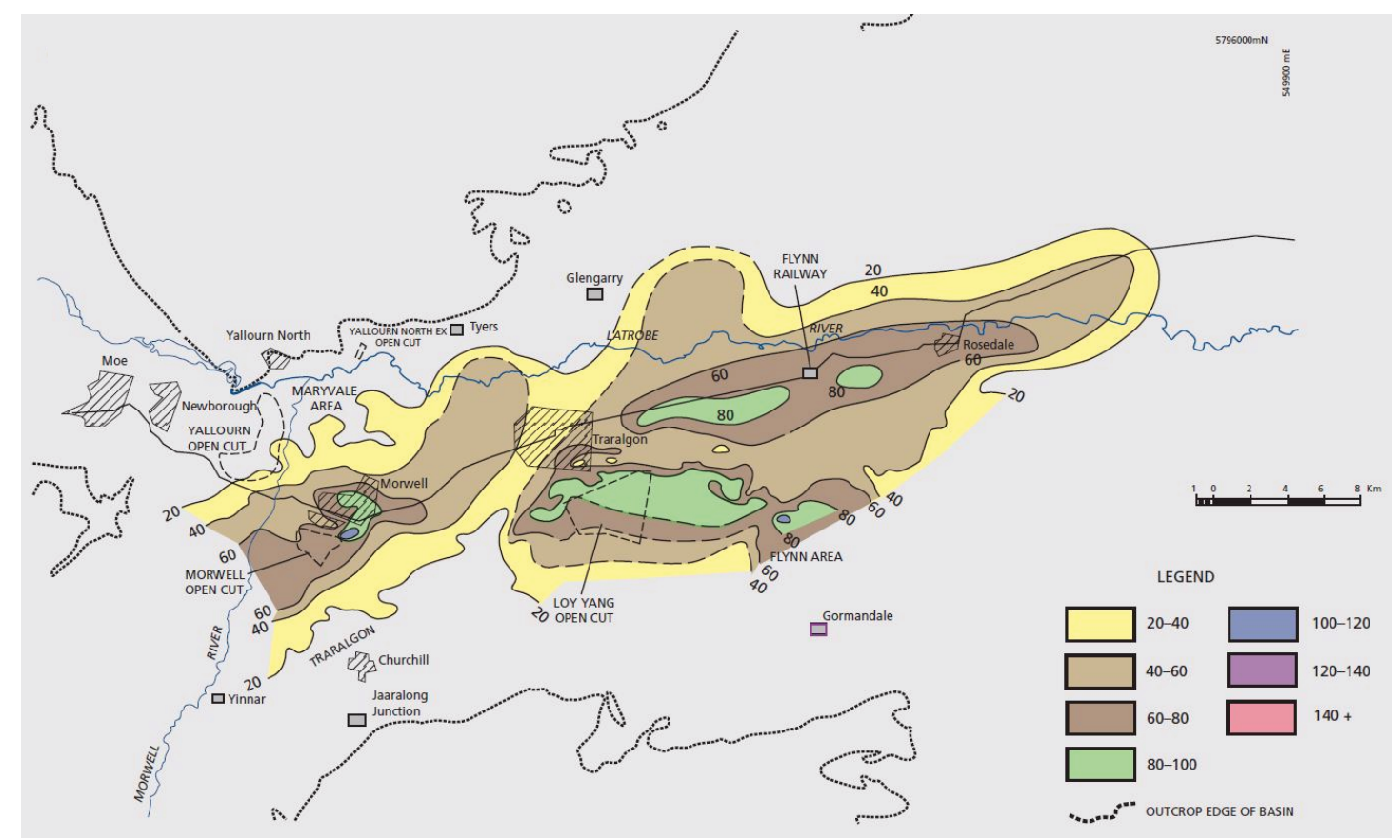

Figure 3 Latrobe Valley isopach map for M1A lignite seam (Holdgate 2003)

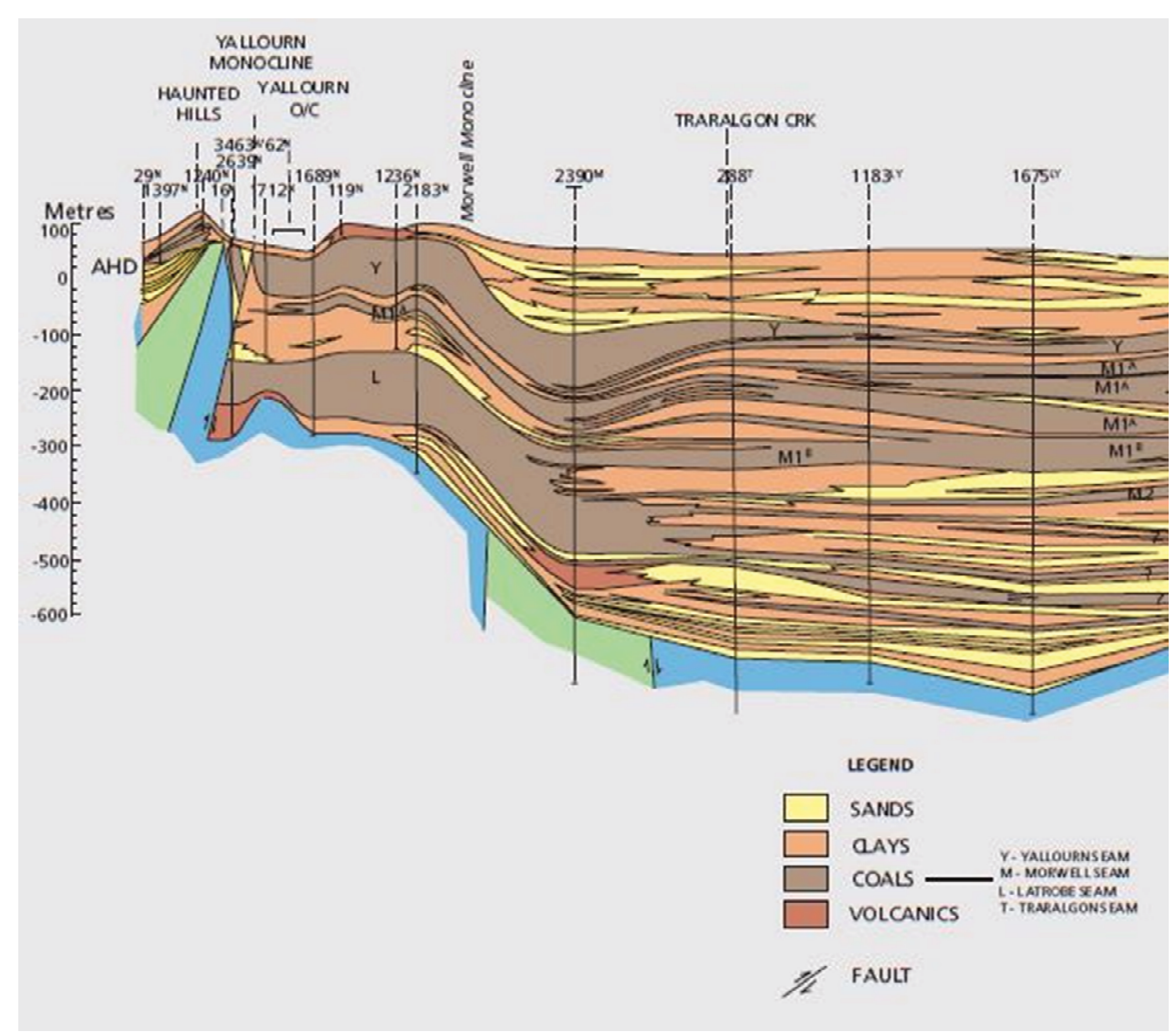

Figure 4 Latrobe Valley west-east stratigraphic section for Yallourn-Hazelwood sector (Holdgate 2003)

The Latrobe Valley lignite resource is the predominant energy source for Victoria (Holdgate 2003). Of particular geotechnical significance, the proportion of overburden and interburden sediments to lignite is very low relative to the proportions found in the Permian black coal deposits. Low lignite density and high 
groundwater pressures combine to create geotechnical challenges for mining operations and post-mining rehabilitation planning.

\subsection{Other overburden materials}

The Permian, Triassic, and Jurassic coal deposits have been subjected to multiple major geological events involving burial, tectonic deformations, and uplift with erosional unloading. Overburdens reflect this variability and also reflect the chemical impacts of long periods of weathering and palaeo-landform development. Wide-scale Palaeogene-Neogene basin development has now largely been removed by erosion. Multiple episodes of volcanism have impacted coal deposits, most significantly basaltic volcanism commencing in the Oligocene and Miocene and continuing, in some areas, into the Holocene. Widespread lavas, ash layers, and hyaloclastites form spatially complex deposits mantling a deeply weathered palaeotopography that has been subsequently weathered and eroded. Such overburdens are of limited geological interest for coal geology and are therefore less explored and characterised for coal mining purposes, presenting challenges for development of robust geotechnical models.

\subsection{Groundwater pressure and flow}

Layered sedimentary rocks provide for potential confined groundwater flow conditions controlled by boundary conditions and relative hydraulic conductivities for each rock unit. At project-scale, these principles have been applied for decades to the problems of predicting groundwater inflows into mine excavations and predicting the spatial nature of groundwater drawdown around mine excavations. Groundwater quality is also of concern when groundwater flows relating to mining operations may transmit substances that are subject to environmental regulation.

Groundwater pressure and flow predictions of this nature require hydrogeological modelling capabilities and parameters for which there is little directly accessible information to guide geotechnical practitioners. While basic principles are provided in Beale \& Read (2013), information specific to coal measures conditions is not so readily available. Large-scale groundwater models are formulated in poroelastic terms governed by the concepts of transmissivity and storativity, which are not directly applied in geotechnical practice. Transmissivity is effectively the product of hydraulic conductivity and interval thickness, while storativity is a measure of the volume of water flow per unit volume of geomaterial per unit change in hydraulic gradient.

Black coal measures rock masses exhibit anisotropic hydraulic conductivity that is dependent on lithotype and fracturing. Coals are typically considered to be of higher transmissivity than interburdens, with all lithotypes except for porous sandstones having low storativity. Hydraulic conductivity information from Mackie (2009) is widely quoted in groundwater modelling for black coal mining projects, for example Smerdon \& Ransley (2012) and Australian Groundwater and Environmental Consultants Pty Ltd (AGE) (2017). Figure 5 is an example prediction of long-term piezometric drawdown for a Hunter Coalfield mining project. Such predictions are not detailed enough to provide groundwater pressure distributions for pit slope stability analyses. Problems arising from application of such modelling capabilities to uncertain geological settings have been highlighted by Currell et al. (2017). Most geotechnical slope stability analysis codes include detailed groundwater pressure modelling capabilities that usually are not coupled to poroelastic response but include flow anisotropy. Such capabilities are still problematic when applied to uncertain geological settings.

Hydrogeological information for the Gippsland Basin is well summarised in Bioregional Assessments (2018). Stratigraphic conditions form a sequence of aquifers and leaky aquicludes (Figure 6) resulting in groundwater pressure distributions and flows that dominate geotechnical stability considerations for the Latrobe Valley lignite mining operations and post-mining rehabilitation (Hazelwood Mine Fire Inquiry 2016). Large-scale groundwater models have been utilised for managing groundwater resources and to predict subsidence caused by depressurisation. Figure 7 shows measured subsidence contours and linkage to brown coal mining operations. 


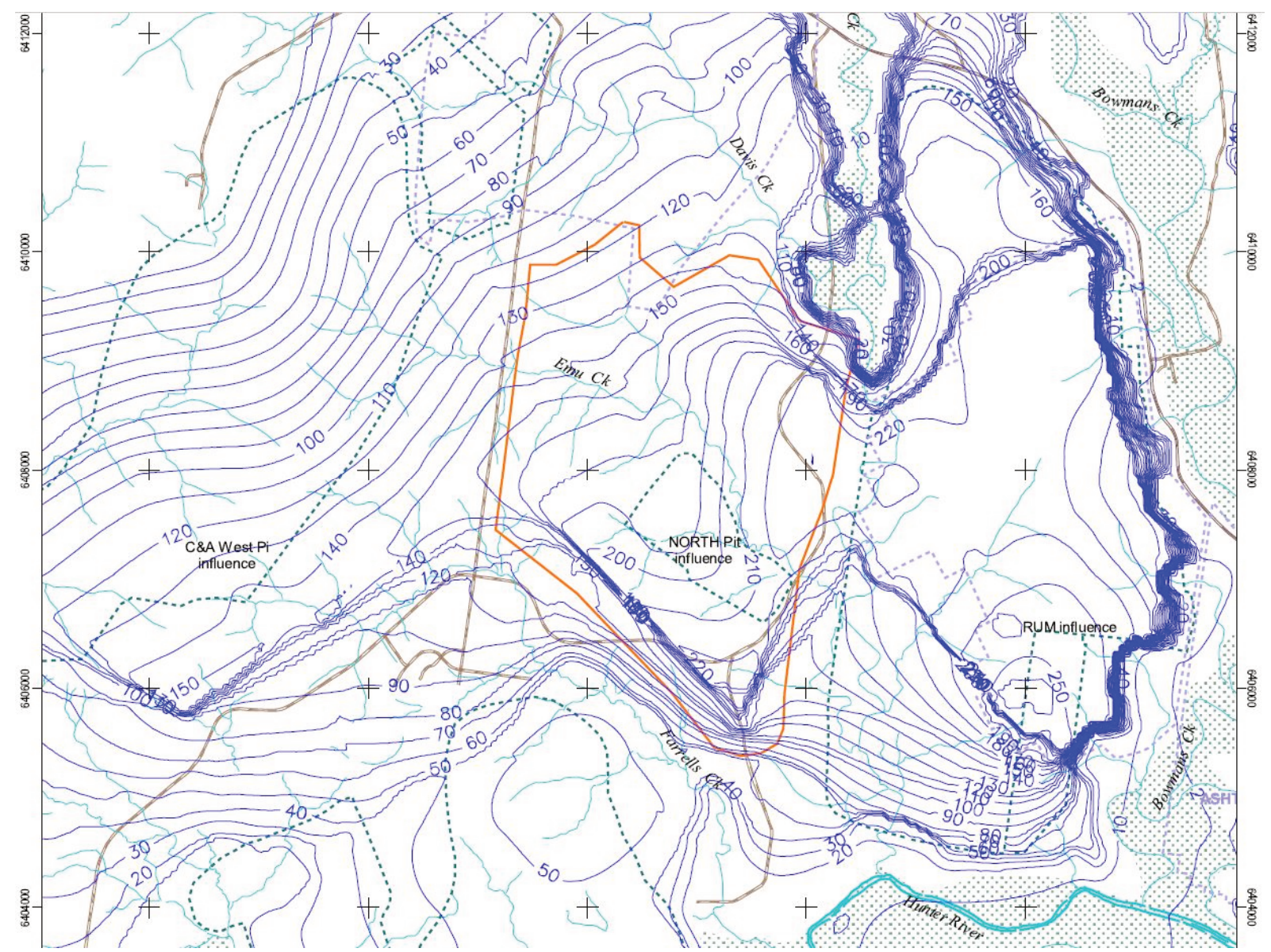

Figure 5 Predicted lateral extent of piezometric surface drawdown in response to proposed open cut coal mining, Hunter Coalfield (after Mackie Environmental Research 2009)

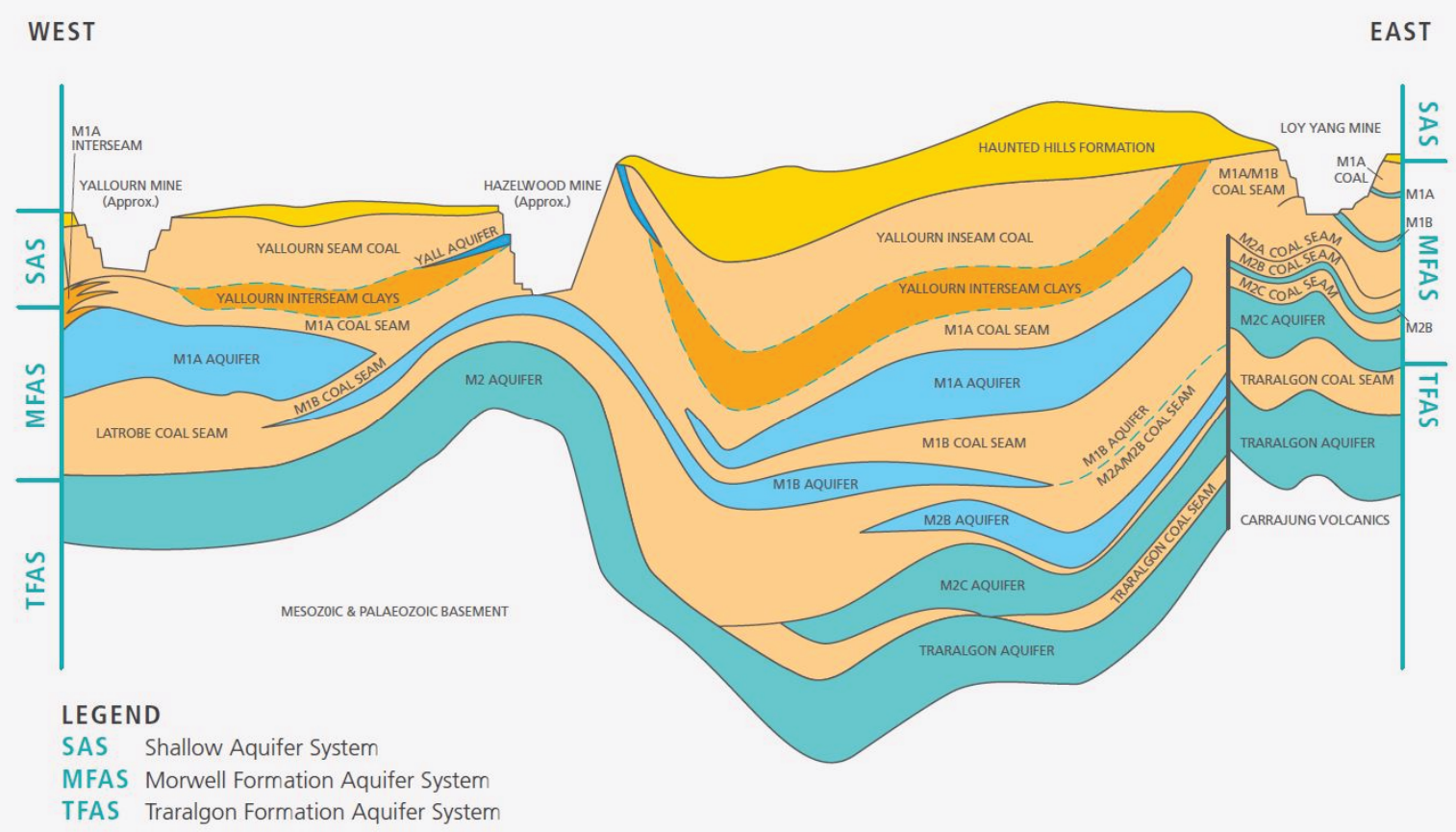

Figure 6 Diagrammatic Latrobe Valley cross-section showing the interrelationships between the coal seams and aquifer systems (Hazelwood Mine Fire Inquiry 2016) 


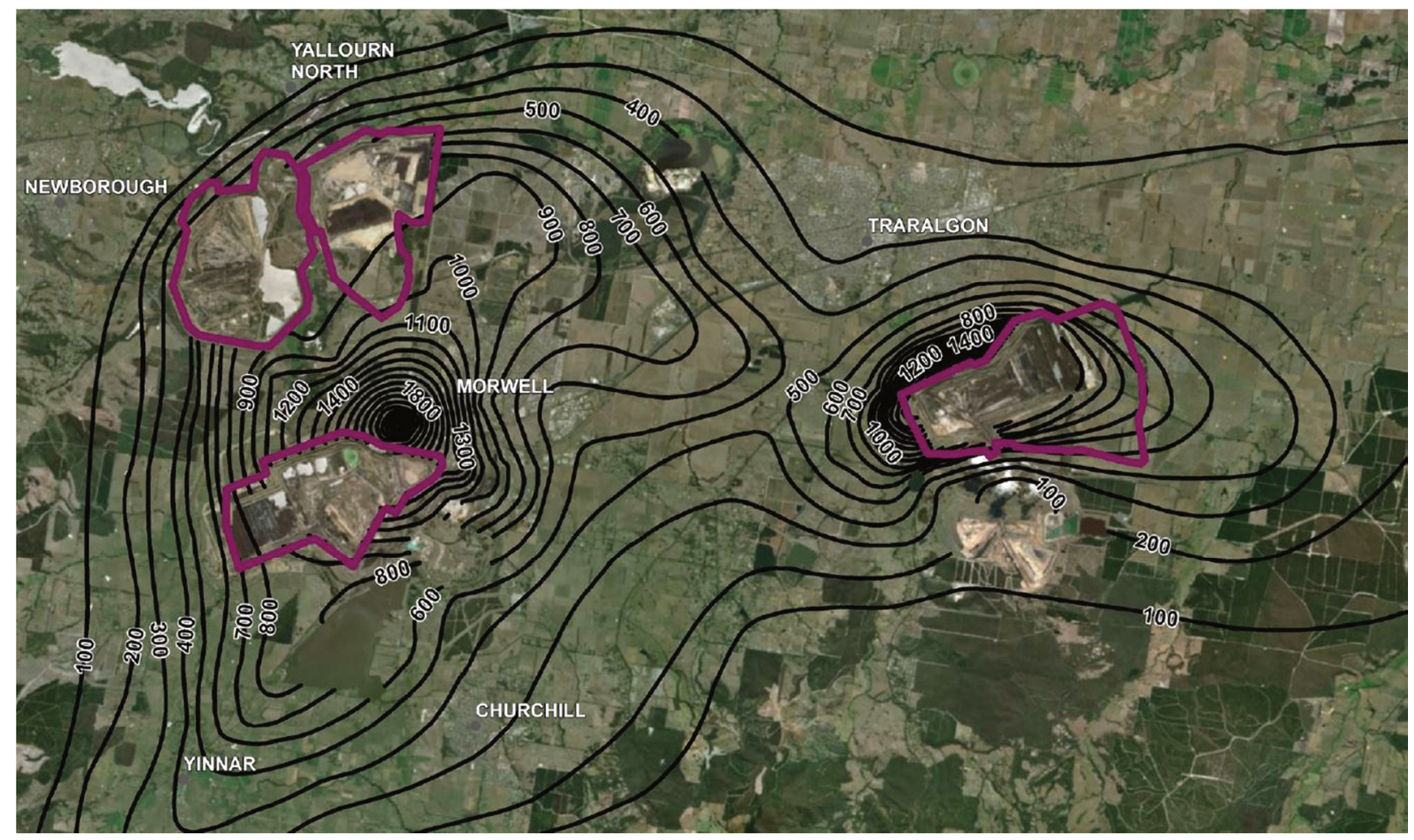

Figure 7 Valley subsidence to 2015, contours in mm (Department of Jobs Precincts and Regions 2019)

\section{$3 \quad$ Black coal mining operations}

\subsection{Excavation and coal recovery}

Large-scale coal mining requires appropriate excavation and transport equipment and very large-scale drilling and blasting practices. Overburdens are characterised as free-diggable, e.g. soils, weathered or altered rocks, or previously placed waste requiring rehandling; or requiring blasting. Free-dig limits in weak rocks depend on material strength and defect fabric but an upper uniaxial compressive strength (UCS) limit of $3 \mathrm{MPa}$ is useful for guidance.

To minimise rock mass damage within pit slopes and thereby minimise the creation of rockfall or instability hazards, controlled blasting is undertaken where possible and is followed by tight face trimming. Ideal tight face conditions require pre-split blasting in advance of production mass blasting. In practice, this may not be possible due to environmental (noise) or production schedule constraints, and control is attempted by stemming pre-splits, firing the pre-split and production blasts together in a tight sequence (mid-splitting), or by using stab-holes in the hope of achieving a relatively tight excavated face at an intended design batter (buffer-blasting). Unlike the 'hard rock' mining sector, trim blasting is not economic for large-scale black coal mining. The Australian industry is also notoriously unable to achieve effective outcomes when trim blasts are attempted for geotechnical hazard control purposes.

Unbenched slope batter heights for current equipment fleets and typical overburden sequences are typically limited to 45-75 m, which reflects drill capabilities and practical limitations on the volume of rock subjected to a single blast. Blasts are typically fired in patterns with delays to achieve vibration limitations. Blast dimensions and patterns are usually designed without reference to geotechnical constraints, but in some instances, preferred geotechnical outcomes may be achieved through appropriate detailing of blast designs. Blasted slope batters typically range from 65 to $75^{\circ}$, and occasionally $90^{\circ}$, and are preferably designed with geotechnical input based on rock mass structure-controlled face stability considerations (McQuillan et al. 2018).

Softwalls are sometimes designed as alternatives to tightly trimmed excavated slopes. A softwall face is excavated within blasted material, either to a uniform design batter or more expediently as a 'flitch-benched' 
slope having an averaged batter angle ('flitch' is the term used for each vertical step in an excavated slope, with the flitch height based on greatest productivity for a particular machine configuration). Softwalls are effectively granular soil slopes with typical batter angles of $45^{\circ}$ and typical unbenched heights (ignoring small-scale flitches) of up to $50 \mathrm{~m}$.

All excavation equipment has operating constraints which are significant considerations for pit geometry optimisation and geotechnical stability assessment. Draglines dominated coal mining earlier in Queensland due to the combinations of relatively flat seam structure dip, relatively thick coal seams, and relatively thick interburdens. Shorter project life cycles and more flexible operating conditions, together with comparable production rates in more recent times, have seen shovels, excavators and bulldozing playing an increasing role in deeper pits and more structurally challenging geological conditions. Part of the geotechnical practitioners' toolkit is a practical understanding of the operational limitations associated with all mining equipment.

Historically, control of groundwater pressure has not been a critical design requirement for excavated slopes. Monitoring of groundwater pressures is not generally undertaken, and depressurisation drainage is relatively rare. For deeper excavations, more complex geological conditions, and more recent corporate emphasis on validation of design assumptions, multiple-sensor piezometers are being increasingly installed. This can be difficult and expensive, leading to reluctance when the operating life of the equipment may be short due to the rate of mining advance.

\subsection{Waste handling}

Configuration and development of overburden and interburden waste dumps is a primary cost driver for black coal mining economics. Dumped waste rock (or spoil, the terms are used interchangeably) behaves as a coarse-grained structured soil and is less dense than in situ rock. Geotechnical guidelines that are specifically tailored to black coal dragline and truck waste dumps (Simmons \& Yarkosky 2017) assume that mine planning engineers can implement slope profiles designed to achieve adequate stability. Slope designs should therefore include equipment- and pit-specific factors that may influence dump slope profiles that can be achieved in practice.

Generally, waste dump profiles are as steep as the governing stability circumstances permit. Operational contingencies may result in dumping actions that compromise slope stability. Runoff water and mud will accumulate at lower levels and generally require removal or limitation to achieve stable dump foundations. Sub-floor weakness or artesian groundwater pressures may also compromise dump stability and may not always be adequately recognised when dumps are designed. Monitoring strategies are therefore required to identify and mitigate the consequences of instability hazards that may arise.

Run-of-mine (ROM) coal usually requires processing to meet product specifications. The alternative is very selective mining which typically is less productive and is only suited to certain coal products. Processing is inevitably water-based to control dust and remove inferior coal and stone bands or overburden contaminants. Coal handling and process plants (CHPPs) traditionally generate two streams of waste: coarse plant rejects (CPR) and fine plant rejects as tailings slurry. Environmental permit conditions and site-specific topographic constraints limit the opportunities for placement of both CPR and tailings.

Most black coal mining operations manage CPR and tailings streams separately with CPR (carbonaceous silty gravel with fines) being placed in overburden dumps or separately designated rejects dumps. Tailings slurry is deposited into containments, either purpose-built dams or mined-out voids. When filled, tailings containments must be capped to comply with site-specific environmental management conditions. Capping is geotechnically challenging, can be expensive, and very tedious if undertaken using standard mining equipment that is unsuited for the capping tasks. Stability assessments for tailings capping involve application of soft soil geotechnical engineering principles and tailings containments are amenable to in situ testing. Despite evidence that capping can be achieved safely and efficiently there is now a widespread industry view that separate tailings containments are unacceptably risky. 
Alternative CHPP waste handling strategies involve dewatering tailings to a semi-solid condition and blending with CPR to form a wet fines-rich soil (mixed plant rejects or MPR) that is trucked to selected locations within the overburden dumps. Some sites elect to dump MPR loads semi-randomly using the same tipheads as used for overburden spoil loads. Other sites prefer to construct a network of shallow cell layers within the dump structure that are covered with inert layers prior to establishing the next MPR cell layer. Stability assessments for waste dumps incorporating MPR require application of both unsaturated and saturated soil mechanics principles (Koosmen et al. 2015). Environmental management criteria for such structures have been developed. Medium-term proof of satisfactory geotechnical performance is-self-evident at mines that have adopted MPR technologies, but long-term proof of satisfactory geochemical performance is yet to be established.

\subsection{Spontaneous combustion and fire control}

Black coals exposed to atmospheric oxygen may be prone to spontaneous combustion. Known susceptibility factors include geochemistry of coal macerals and inclusions such as pyrite, exposure to airflow, and climate and improved susceptibility tests are now available (Beamish et al. 2015). Combustion usually results from self-heating which can be readily detected using infrared imaging equipment. Once sufficiently heated, coal fires produce all the solid and gaseous fuel required to be self-sustaining without access to further atmospheric oxygen and can be difficult to extinguish. Preferred control methods are flooding, which is dependent on the availability of sufficient water, or spreading and mixing or covering with sufficient inert material once the temperatures have been reduced below the self-sustaining level. Such procedures are usually refined by trial and error as individual sites may have different combinations of operational constraints.

\section{$4 \quad$ Brown coal mining operations}

\subsection{Excavation and coal recovery}

Large-scale power generation in the Latrobe Valley requires very high excavation rates using either bucketwheel excavators or bulk dozing to feeder-breakers for lignite extraction, with supplementary excavator-truck removal of overburden and interburden sands and clays. Lignite is transported by conveyor systems to stockyards at power stations. The advancing mine slope profiles comprise broad operating benches to accommodate such large-scale extraction processes within thick seams (Waghorne 2009). Inter-ramp and overall slope angles are also relatively flat due to geotechnical stability constraints resulting from very low lignite densities, potentially very high groundwater pressures, and the presence of low strength interseam clay layers. Mine footprints are very large to accommodate mining depths to $250 \mathrm{~m}$.

Joints, fracture zones, and minor faults are well developed within the lignite deposits, typically at high angles to depositional structure and usually at wide spacings due to the seam thicknesses. Pre-mining erosional stress relief and excavation-induced stress relief readily cause opening of such defects, allowing water and sediments to circulate relatively easily. Lignite is also readily combustible, so that weathered and near-surface deposits may incorporate large-scale inclusions called fireholes infilled with ash and weak sediments. Mining infrastructure must include effective surface drainage and measures to suppress spontaneous combustion, and fireholes must be adequately defined ahead of mining.

Hydrogeological conditions provide the greatest geotechnical challenges for the Latrobe Valley mines. Geotechnical stability is achievable only through large-scale depressurisation of the highly permeable aquifers within the interseam sediments and below the pit floors. All mining operations have large-scale pumping facilities to form a depressurisation zone to overcome floor heave and wall instability. For deeper excavations, the depressurisation of aquifers by pumping must be supplemented by networks of horizontal drains to widen the drawdown effect and provide pressure relief for joints which could otherwise fill with water and potentially result in block slides on weak interseam clays.

Large-scale and long-term mining-induced depressurisation of the Latrobe Valley aquifer systems has extracted a large volume of water from void space while increasing the effective stresses within the coal measures sequence. Regional subsidence in excess of $2 \mathrm{~m}$ has been measured as a consequence (Waghorne 
\& Disfani 2019). Localised differential settlements associated with such subsidence have had some impacts on individual properties but are important considerations for movement-sensitive infrastructure including surface drainage, transport corridors, and pipelines. Depressurisation and subsidence considerations are equally significant for post-mining geotechnical conditions.

\subsection{Waste handling}

Waste dumps must be carefully planned in coordination with the depressurisation pumping facilities so that the placed material can provide a blanket resisting floor heave and a buttress resisting lateral instability. Overburden and interburden waste materials are also used for the construction of combustion ash retention facilities. Overburden waste materials range from sands and gravels to silty sands and clays and very low strength claystones. Overburden clays may be sodic and highly dispersive, requiring great care if considering use for liquid-retaining embankments retaining liquids. For example, the Morwell River was diverted across a mined-out section of Yallourn Mine in order to access East Field coal by means of an open channel constructed on top of a large embankment. The channel structure failed by piping erosion when carrying its first major flood, with failure attributed to inadequate embankment zoning and filter design (Seddon 2013).

Combustion ash is returned, generally as a slurry, to retention facilities which provide some buttressing and weighting function, if located in-pit. Such facilities require the same level of geotechnical assessment as tailings dams and are also subject to the depressurisation constraints of the active mining operation.

\subsection{Spontaneous combustion and fire control}

Lignite exposed to atmospheric oxygen is prone to spontaneous combustion or may combust readily under external stimuli such as bushfire ember attack. Once ignited over a sufficient volume, lignite fires produce all the solid and gaseous fuel required to be self-sustaining without access to further atmospheric oxygen. Suppression of lignite fires is reliant mainly on the comprehensive application of sprayed water and a fire suppression system composed of a pipeline network and spraying units should be capable of covering all exposed lignite surfaces.

\section{$5 \quad$ Geotechnical characterisation}

\subsection{Significance of coal rank}

Australian Permian and Triassic black coals are of bituminous rank while Jurassic black coals are sub-bituminous. Palaeogene-Neogene brown coals are of lignite rank. Consider the simplified summary of coal rank in Table 1.

Table 1 Simplified summary of coal rank (after GNS Science 2020)

\begin{tabular}{lllll}
\hline Coal rank & $\begin{array}{l}\text { Burial depth } \\
(\mathbf{k m})\end{array}$ & $\begin{array}{l}\text { Estimated } \\
\sigma_{\mathrm{P}}^{\prime}(\mathbf{M P a})\end{array}$ & $\begin{array}{l}\text { Maximum temperature } \\
\left({ }^{\circ} \mathbf{C}\right) \text { during burial }\end{array}$ & $\begin{array}{l}\text { Moisture } \\
\text { content }\end{array}$ \\
\hline Peat & $<0.2$ & 3.0 & $0-25$ & $50-80 \%$ \\
Lignite & $0.2-1.5$ & $3.0-22.5$ & $25-40$ & $30-50 \%$ \\
Sub-bituminous & $1.5-2.5$ & $22.5-37.5$ & $45-75$ & $10-30 \%$ \\
Bituminous & $2.5-6$ & $37.5-90.0$ & $75-180$ & $5-10 \%$ \\
Anthracite & $>6$ & $>90.0$ & $>180$ & $<5 \%$ \\
\hline
\end{tabular}

Essentially, rank reflects burial history. Indicative temperatures in Table 1 are determined from two approaches: the typical geothermal gradient below ground surface and the identification of thermally constrained organic compounds, with these temperatures generally reflective of burial depth. Despite different and incompatible meanings that geotechnical engineers and sedimentary geologists assign to the term 'consolidation', there is common understanding of sedimentary compression under load. Coal rank should be a helpful concept for engineers to predict the geotechnical properties of coal measures rocks. 
Textbook examples of 1D compression of soil (e.g. Holtz \& Kovacs 1981) are limited to stress levels of geotechnical significance that are, in geological terms, relatively small. Compression test data alone does not include the time-dependent consolidation resulting from transient pore pressure dissipation under relatively rapid total stress changes. Time-dependent thermal effects and chemical processes are not represented. Extrapolating an example soil compression curve to the burial vertical stress range in Table 1 for bituminous coal would result in a void ratio of 0.08 or less. A saturated coal measures sedimentary rock with a void ratio of 0.07 and an average mineral particle density of 2.7 would have a moisture content of about $2.5 \%$. The author's coal measures rocks records for such moisture contents are linked to a UCS range of 20-40 MPa. Similar calculations for sub-bituminous Eocene coal measures rocks from Kalimantan, Indonesia (e.g. Figure 8.7 from Martin \& Stacey 2018) predict a moisture content in the range of $5 \%$ linked to a UCS range of 5-12 MPa, typical of UCS test data. These rocks have similar coal rank, moisture content, and UCS ranges to Australian Jurassic coal measures rocks.

The Australian brown coals (lignites) of the Latrobe Valley in Victoria are characterised by relatively thin and essentially unlithified overburdens, multiple seams with thicknesses ranging from $10 \mathrm{~m}$ to more than $100 \mathrm{~m}$, and interburdens best described as hard soils to very low strength rocks. Natural moisture content for lignites ranges from 200 to 100\% (Trollope et al. 1965; Holdgate 2005; Figure 8). Despite such remarkable moisture contents, lignites are best described as hard soils or extremely low strength rocks.

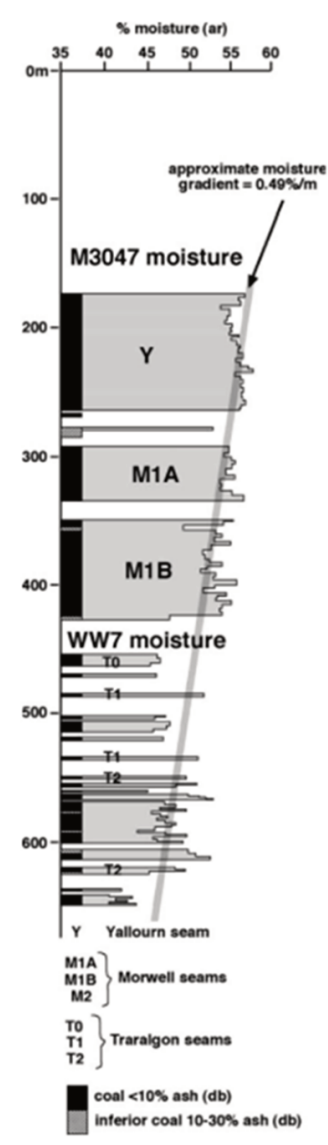

Figure 8 Downhole moisture content between 180 and $650 \mathrm{~m}$ in the Traralgon Syncline (Latrobe Valley) and Seaspray Depression. Also shown is the moisture gradient (Holdgate 2005)

Coal measures materials are products of a limited range of deposition processes and vary laterally and vertically in geologically predictable ways (Selley 1996). Lithification may be considered as compaction due to burial with some additional effects of mineral composition and shape changes resulting from pressure-temperature-time effects. Petrological observations and tests on (non-coal) coal measures rocks identify silicate or lithic particles and binding agents that are either carbonates or silicates (from diagenesis) or phyllosilicates (extremely desiccated clays). In the absence of robust diagenetic binders, coal measures 
rocks can rapidly degrade and weather when unloaded and exposed to atmospheric humidity and oxygen. Apparently, strong spoil particles can decompose within a period of weeks to months after blasting and dumping (Fityus et al. 2015).

Broader thermodynamical processes that apply to sediments buried for geological time periods are not discussed here. Coal measures rock masses may also have been subjected to igneous intrusion or volcanic cover where localised thermal or hydrothermal alteration processes add complexity to the materials exposed by mining processes. In the absence of such complexities, the rank of a coal deposit can be readily determined from vitrinite reflectance measurements. Coal rank and in situ moisture content of non-coal rocks should provide a reliable indication of material strength; the higher end of the strength range being associated with carbonate or silicate binders.

\subsection{Black and brown coals as geomaterials}

Physical and chemical characteristics of black coal reflect wide ranges of source organic materials, accumulation settings, and thermodynamic formative reactions. In theory, all fresh coal materials are cohesive enough to readily enable sampling and testing. However, they are also structured, and intact coal material becomes increasingly difficult to sample and test as rank increases. Black coals of similar rank can be subdivided in terms of brightness; a geological term that captures differences in macerals within the accumulated layers of organics that started as peat and were transformed by pressure and temperature into plies. Coal plies are typically fractured by centimetre-scale orthogonal cleats as described by Medhurst \& Brown (1998) so that black coal samples inevitably behave as small-scale rock masses. In addition to scatter resulting from inevitable sampling damage, significant scale effects should be expected when testing 'intact' core specimens of coal. Medhurst \& Brown (1998) described results of triaxial tests on a range of core diameters and discussed an approach for characterising coal material strength.

The Latrobe Valley brown coals also reflect wide ranges of source organic materials, accumulation settings, and thermodynamic formative reactions. Because of their low rank and limited compression history, lignites are typically thick bedded to massive and it is relatively straightforward to extract intact samples for testing. Lignite deposits are nevertheless geological materials and contain sedimentary contacts, joints, and tectonically induced fractures. These present as a structured very low strength rock mass amenable to geotechnical characterisation.

\subsection{Virgin and pre-existing stress states}

Deformations resulting from excavation-induced stress changes depend on material deformability, geometry, and the pre-existing or virgin stress state. Virgin stresses within the Australian continent are complex and vary with tectonic setting (Hillis et al. 1999; Rajabi et al. 2017). When considering pit slope deformations in current mining areas, the pre-existing stress state will already have been modified from the virgin stress state by prior mining activities. Geotechnical models of mining-induced ground movements must therefore commence with a simulation of the virgin stress state plus any changes caused by prior mining.

Mining operations utilise movement monitoring technologies for managing safety by providing advanced warning of potential instability. Interpretation of deformation measurements is currently based on empirically derived movement thresholds. Movement interpretation based on deformation prediction is likely to become more widespread in future as modelling capabilities develop, but this will require appropriate determination of pre-existing stress states. Site-specific stress measurements are more widely made for underground coal mining geotechnical studies but may be increasingly required for open cut coal mining for deformation prediction modelling.

Black coal mining areas within the Sydney-Gunnedah, Bowen, and Surat Basins have been subjected to a complex tectonic regime which has left its record in the rock mass defect patterns. Currently, these areas are 'relatively quiet' but not immune from intraplate earthquake activity. In situ stresses are relatively well understood due to the source locations and nature of the earthquake activity and widespread measurements for underground mining project purposes. 
The Latrobe Valley lignite deposits formed under an extensional tectonic regime where lateral stresses would be modest and predictable using soil mechanics theory. Subsequently, the lignite deposits have been subjected to a compressional regime. The Latrobe Valley is considered by seismologists to be the most seismically active region of the continent and is currently under detailed monitoring due to public awareness of earthquake activity and the critical importance of the mines and power stations to energy production. In situ stresses are relatively well understood due to the source locations and nature of the earthquake activity and the widespread interpretation of in situ stresses related to production considerations from the neighbouring Gippsland Basin petroleum resource fields.

\subsection{Exploration data from drillholes}

Cost-effective mining relies on large-scale operations, for which mine plans require effective and economically reliable geological models. Lateral and vertical variability requires models based upon drillhole spacings that are limited in order to achieve acceptable model reliability. Models include physical location information and a range of resource moisture, energy content, and chemistry attributes. Physical attribute testing is vital, drillhole spacing is progressively reduced, and infill testing is undertaken to provide appropriate model confidence.

Logging of geological and geotechnical exploration data from Australian black coal mining projects has been computerised since the mid-1960s. As computer systems proliferated, so did versions of the original coding systems. CoalLog (Green 2015), an initiative of industry practitioners, rationalised information gathering and communication. Most significantly for geotechnical practitioners, coding of geotechnical data has been harmonised with AS 1726:2017 (Standards Australia 2017) for geotechnical site investigations, and this included changing geological descriptors of grain size, plasticity, and visual-tactile strength to conform with geotechnical practice. The black coal industry and regulatory bodies now recognise CoalLog as default industry practice.

Geological assessment of drillhole data has evolved to rely upon geophysical logs supplemented by more widely spaced coring for additional data. Drilling specifically for geotechnical data gathering is relatively infrequent and is generally targeted to managing identified design-level risks for projects in advance of mining operations. It is therefore advantageous for geotechnical practitioners to be familiar with basic interpretation of geophysical log data, and to utilise such data in formulating geotechnical models.

Geophysical log data is directly relevant to geotechnical data interpretation. In situ density logs provide accurate total density, gamma logs are sensitive to ${ }^{40} \mathrm{~K}$ content that usually indicates high activity clays with potentially low shear strength, and calliper logs provide an indication of localised fracture intensity or weakness. Gamma logs may also indicate a 'kick' associated with groundwater saturation and may distractingly show 'high activity' due to high levels of ${ }^{40} \mathrm{~K}$ from feldspars in lithic arenites. Sonic velocity logs respond to elastic modulus of rock material, which is correlated to UCS and therefore, widely used to interpret in situ rock material strength. UCS-sonic correlations are notoriously variable, and this is often attributed to lithological differences but may just as likely reflect core quality and core sampling bias issues.

\subsection{Bulk samples and exploration by mining}

From time to time, resource evaluations requirements may require bulk coal samples from test pits. Such excavations provide an opportunity for geotechnical observations and sampling. As with all geotechnical bulk samples, either 'undisturbed' (at a minimum, stress relief is unavoidable) blocks or mass samples may be collected and if necessary, reconstituted to prepare specimens to be tested for geotechnical parameters.

Geological 'surprises' may be encountered during mining operations because of the inevitable approximations of geological models. When a significant geological uncertainty such as a major fault is predicted or suspected, mining equipment may become the exploration toolkit of greatest value to geotechnical practitioners. Close relationships between mine operators and geotechnical specialists enables maximum value to be obtained from exploration by mining. 


\section{$6 \quad$ Black coal geotechnical models and parameters}

\subsection{Rock material and rock mass shear strength}

This paper is focused on stratified sedimentary coal measures rocks, but many principles will apply in a similar way to other lithotypes present in coal mine overburden, interburden, and intrusives. Much has been written about the scale dependence of rock mass shear strength. Stratified rock masses are structurally anisotropic, and intact sedimentary rock material is likely to also be physically anisotropic as a result of depositional processes, burial stresses, and diagenetic processes.

Anisotropic shear strength models are not widely utilised because of the obstacles that arise in practice for determining representative model parameters. From a practitioner perspective, isotropic shear strength models have proven to be adequate for most design purposes. The Generalised Hoek-Brown (GHB) shear strength criterion (Hoek \& Brown 2018) has been widely adopted for 'hard rock' mining applications and there has been a natural tendency to apply it to 'soft rocks' like coal measures. This tendency has persisted despite the continuing caveats placed on its range of applicability by its originators.

Rock material shear strength can be reliably determined from confined and unconfined compression and extension testing. Industry data is biased towards rock materials that can be successfully cored and to UCS tests on core. Open cut stability problems require a working knowledge of rock mass strength, for which the GHB criterion requires the introduction of scaling factors geological strength index (GSI) and D. Selection of GSI is problematic in coal measures rock unless rock quality designation (RQD) is accurately logged at the time of coring, and is problematic anyway because of anisotropy at all scales.

In many circumstances, geotechnical practitioners do not have the access or resources to assess rock mass shear strength using site-specific data and the GHB methodology. In the absence of better and more site-specific alternatives, Table 2 lists generic Mohr-Coulomb shear strength parameters for Permian bituminous coal measures, while Table 3 lists parameters for Jurassic sub-bituminous coal measures.

Table 2 Nominal shear strength parameters for bituminous coal measures (after Simmons et al. 2018)

\begin{tabular}{lllll}
\hline Material & $\begin{array}{l}\text { Uniaxial compressive } \\
\text { strength (MPa) }\end{array}$ & $\gamma\left(\mathbf{k N m}^{-\mathbf{3}}\right)$ & $\mathbf{c}^{\prime}(\mathbf{k P a})$ & $\boldsymbol{\phi}^{\prime}(\mathbf{d e g})$ \\
\hline Weathered non-coal & $1-3$ & $22-23$ & $115-300$ & $32-37$ \\
Fresh non-coal & $10-25$ & $24-25$ & $450-500$ & $42-43$ \\
Weathered coal & $1-3$ & $14-15$ & $5-15$ & $30-32$ \\
Fresh coal & $5-15$ & $14-15$ & $35-50$ & 35 \\
\hline
\end{tabular}

Table 3 Nominal shear strength parameters for sub-bituminous coal measures (Simmons, pers. files)

\begin{tabular}{lllll}
\hline Material & $\begin{array}{l}\text { Uniaxial compressive } \\
\text { strength (MPa) }\end{array}$ & $\gamma\left(\mathbf{k N m}^{-\mathbf{3}}\right)$ & $\mathbf{c}^{\prime}(\mathbf{k P a})$ & $\boldsymbol{\phi}^{\prime}(\mathbf{d e g})$ \\
\hline Weathered non-coal & $0.5-1.5$ & $22-23$ & $50-75$ & $22-28$ \\
Fresh non-coal & $3-12$ & $24-25$ & $150-250$ & $38-42$ \\
Weathered coal & $1-3$ & $14-15$ & $5-15$ & $30-32$ \\
Fresh coal & $5-15$ & $14-15$ & $35-100$ & 35 \\
\hline
\end{tabular}

The tabulated shear strength parameters are pseudo-empirical as they were not derived by guesswork ('trial and error') but from multiple 2D limit equilibrium back-analyses of a range of rock slope profiles based on the assumption that slopes showing no signs of cracking or instability should have a Factor of Safety (FOS) of at least 1.2. The tabulated tensile strengths are based on numerical modelling experience where strengths have been adjusted to match observed conditions for onset of tension cracking.

In current practice, there is no alternative to shear strength models that have significant limitations. This situation may change but will take time. Recent advances in numerical modelling have provided an 
opportunity to generate rock mass shear strength models for synthetic rock masses (SRM) derived from defect mapping data and rock material fracture behaviour. Figure 9 (M Tsang, pers. comm., March 2020)) is a comparison of Mohr-Coulomb models for a Bowen Basin overburden rock mass with a nominal 'representative' UCS of $25 \mathrm{MPa}$. The Table 2 pseudo-empirical parameters, a linear fit to a GHB-determined strength envelope, and three SRM idealisations representing worst-case to best-case bounds. The SRM idealisations were generated from a 2D model section of this rock mass that was subdivided into nine zones (Figure 10). Some important conclusions may be drawn:

- SRM methodology can replicate, using geotechnical field and laboratory data, strengths determined using currently accepted methods.

- Shear strength for a coal measures rock mass is relatively low, given the nominal UCS.

- Differences between models may have the greatest effect on available strength for effective normal stresses less than $2 \mathrm{MPa}$, which are most likely to be present within the depth range of potential rock mass failure mechanisms that are most likely to develop within Bowen Basin open cut pit slopes.

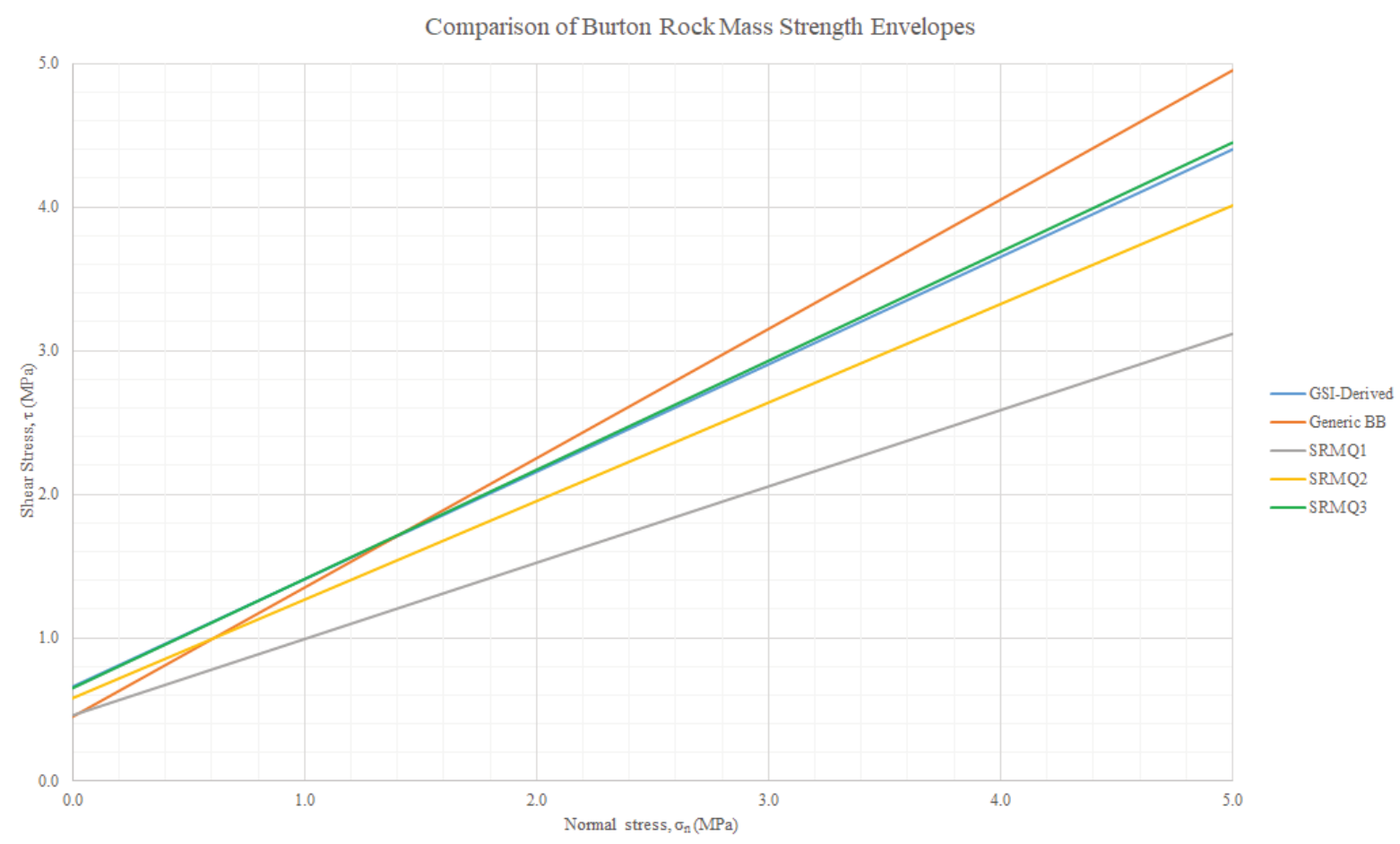

Figure 9 Comparison of shear strength envelopes generated by synthetic rock mass (SRM) models with Generalised Hoek-Brown and empirical rock strengths

The SRM approach can generate further insights regarding rock mass strength mobilisation. Figure 11 is a simulated stress-strain plot from a hypothetical very large-scale UCS test on one of the idealisation zones from Figure 10. Despite the large physical size, the stress-strain curve shape for this test looks remarkably like that from a laboratory-scale test, with the difference being that the rock mass UCS is approximately $10 \%$ of that for the nominal 'representative' rock material. Figure 11 also clearly shows that the growth of extension fracturing completely controls mobilised strength. Significantly, the tensile strength for the SRM model is much lower than what would be determined using the GHB methodology, and the volumetric strain accompanying plastic deformation is largely suppressed at confining stresses greater than about $2 \mathrm{MPa}$. 


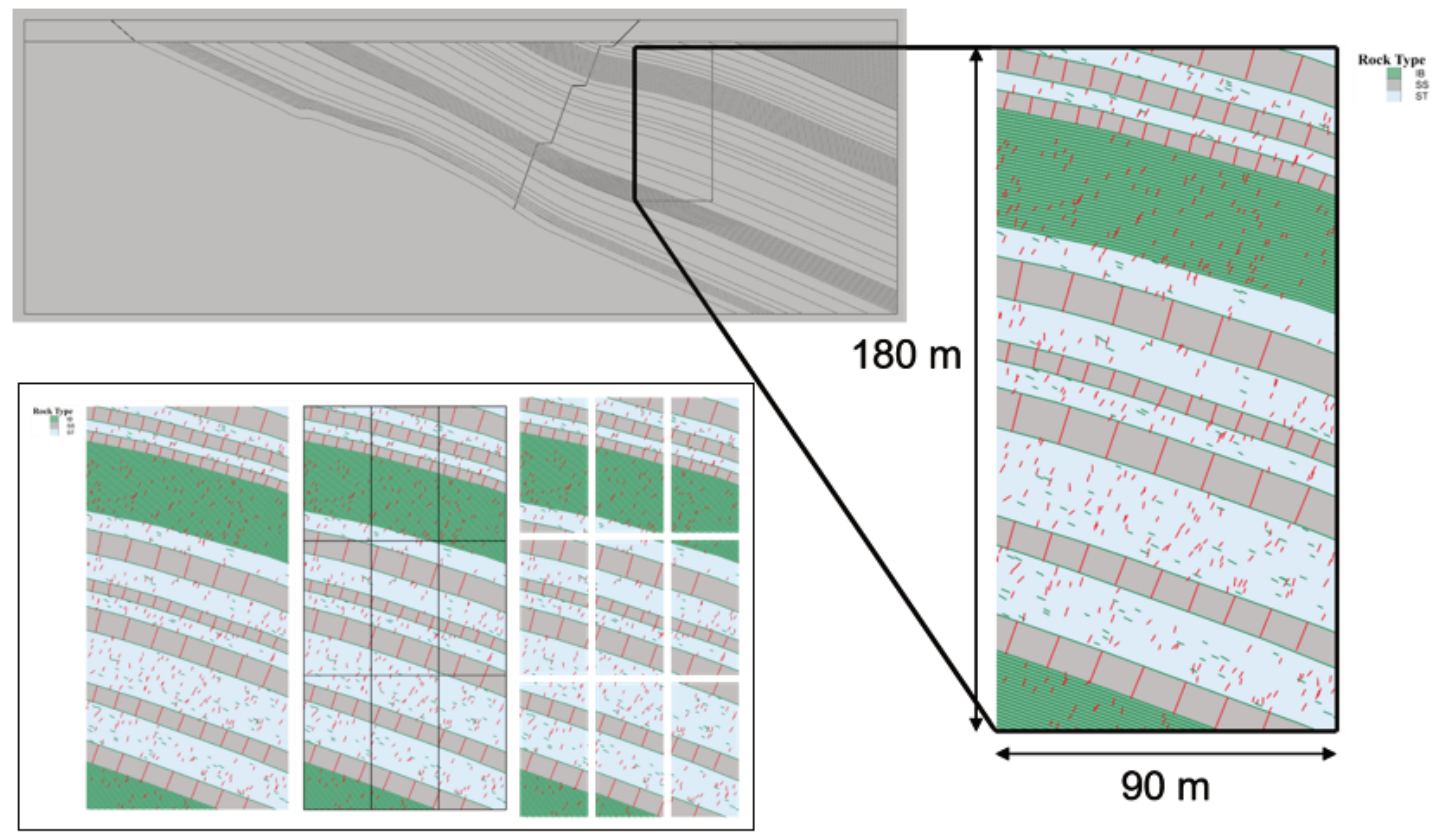

Figure 10 Synthetic rock mass model based on $250 \mathrm{~m}$ highwall rock mass profile in Bowen Basin bituminous coal mine, with subsampling (inset) and defects for block model idealisations of shear strength modelling

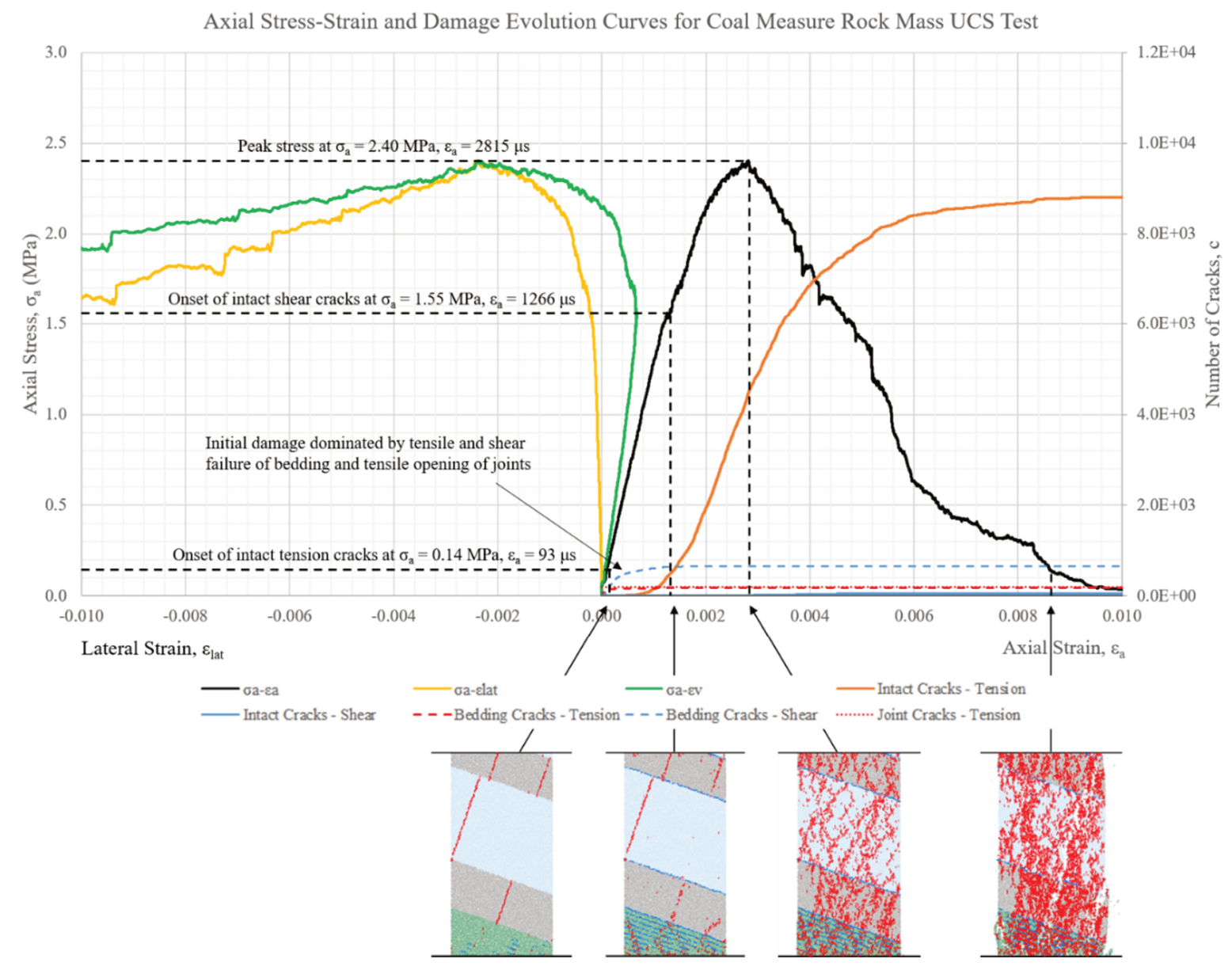

Figure 11 Synthetic rock mass large-scale uniaxial compressive strength test showing evolution of cracking with increasing axial strain 
It may be concluded that while geotechnical practitioners may believe that they have information and tools to successfully model rock mass strength for slope design purposes, there is still much to learn and understand about the role of extension fracturing in slope response to excavation. Extension fracturing within rock material appears to start developing at relatively low pre-failure deformation levels. Better understanding of extension behaviour is most likely to be obtained from further SRM-based research.

\subsection{Rock deformability}

Excavation is primarily an unloading process that generates extensional stress paths within the adjacent slopes of the rock mass. Unloading stiffness is therefore most appropriate for prediction of deformation response. Determination of rock mass stiffness is intrinsically difficult, and there is a relatively small body of accessible information on field-scale stiffness parameters that have been verified by movement monitoring. For guidance, Tables 4 and 5 list stiffness parameters (Young's modulus $E$ and Poisson's ratio $v$ ) and rock mass tensile strength $(t)$ for bituminous and sub-bituminous coal measures rocks that have been derived by the author from laboratory tests on core and ground-truthed using movement measurements and modelling.

Table 4 Nominal deformability parameters for bituminous coal mines (Sherwood Geotechnical and Research Services 2011)

\begin{tabular}{lllll}
\hline Material & $\begin{array}{l}\text { Uniaxial compressive } \\
\text { strength (MPa) }\end{array}$ & $\mathbf{E}(\mathbf{M P a})$ & $\mathbf{v}$ & $\mathbf{t}(\mathbf{M P a})$ \\
\hline Weathered non-coal & $1-3$ & $1,500-2,500$ & 0.25 & $0.010-0.050$ \\
Fresh non-coal & $10-25$ & $2,500-5,000$ & 0.25 & $0.015-0.075$ \\
Weathered coal & $1-3$ & $750-1,500$ & 0.25 & $0.005-0.025$ \\
Fresh coal & $5-15$ & $1,500-2,500$ & 0.25 & $0.005-0.025$ \\
\hline
\end{tabular}

Table 5 Nominal deformability parameters for sub-bituminous coal mines (Simmons, pers. files)

\begin{tabular}{lllll}
\hline Material & $\begin{array}{l}\text { Uniaxial compressive } \\
\text { strength (MPa) }\end{array}$ & $\mathbf{E}$ (MPa) & $\mathbf{v}$ & $\mathbf{t}(\mathrm{MPa})$ \\
\hline Weathered non-coal & $0.5-1.5$ & $1,000-2,000$ & 0.25 & $0.005-0.025$ \\
Fresh non-coal & $3-12$ & $2,000-4,000$ & 0.25 & $0.025-0.075$ \\
Weathered coal & $1-3$ & $750-1,500$ & 0.25 & $0.005-0.025$ \\
Fresh coal & $5-15$ & $1,500-2,500$ & 0.25 & $0.005-0.025$ \\
\hline
\end{tabular}

The tabulated isotropic elastic parameters have some important limitations when applied to rock mass deformation behaviour. Deforming rock masses are likely to experience some non-recoverable plastic behaviour even at stresses well below peak strength. The previously mentioned SRM modelling suggests the onset of non-recoverable deformation at less than $10 \%$ of peak strength mobilisation. Currently, available deformation modelling codes are designed primarily to support elastic-plastic deformation models having simplified peak and residual strengths and a simplified plastic strain dilatancy rate that is not variable with the confining stress. The author's experience is that these models may be used with care, particularly regarding non-zero dilatancy rates, and that the appropriate choice of post-peak strength response depends on the scale of the model and the predominant stress path during plastic yielding. Any person utilising such model capabilities is well advised to check the sensitivity of model outputs to all plasticity parameter inputs and in particular, to not rely on parameter interpretations from laboratory tests on intact core.

\subsection{Degradation and weathering}

Degradation is the time-dependent process whereby rock material disaggregates after atmospheric exposure to oxygen, water vapour, and temperature changes (Fityus et al. 2015). Slaking is a related disaggregation process when atmospherically exposed rock material is immersed in water. Weathering is a more general term for changes to the physical condition of rock after exposure to a full gamut of atmospheric conditions and time periods. All coal measures rock materials will undergo some form of degradation and weathering, 
resulting in changes to geotechnical behaviours. Materials that degrade are particularly susceptible to slaking and erosion after exposure to rainfall and associated water runoff flow across exposed rock.

Rock masses that degrade and weather in exposed slopes will eventually loosen and then become potential rockfall hazards. The hazard generation process may become cyclic when the rates of degradation and erosion are variable in different bedded lithologies, resulting in differential erosion of rock layers. The likelihood of a rockfall is related to the measurable rate of undermining of an erosion-resistant layer relative to the joint spacing in the direction of undermining.

\subsection{Hydraulic conductivity}

Groundwater flow-through coal measures rock masses is a complex process. Mine-scale groundwater modelling is not detailed enough to be useful for geotechnical stability analysis. Basic principles must be followed when making any assessment of groundwater pressure and flow, and even with high-quality piezometer data, it is unlikely that pressure distributions can be understood in detail because of uncertainties arising from anisotropy.

The simplest method for representing groundwater pressures within a slope is a phreatic surface. This is most appropriate in the unconfined flow condition to be expected close to a slope but in reality, there will be significant differences in hydraulic conductivities between different rock beds, due to differences in both material and fracture flow. It is technically incorrect to assume that the groundwater pressure at a particular location below a phreatic surface will be equivalent to the vertical head difference from the point to the phreatic surface. The actual pressure will generally be lower, with the ratio of the actual pressure head to the vertical head represented by the parameter $\mathrm{H}_{\mathrm{u}}$. This is not likely to be constant within a particular slope geometry or even for different locations within individual rock mass units comprising that slope geometry. Modern stability analysis tools allow $\mathrm{H}_{\mathrm{u}}$ to be specified but the problem remains of how best to evaluate $\mathrm{H}_{\mathrm{u}}$. Estimates can be made from piezometer data. The estimates become more meaningful when there are multiple piezometers representing the flow field generally rather than a single value at a single point. An example determination of $\mathrm{H}_{\mathrm{u}}$ is shown in Figure 12 (after Simmons 2019).

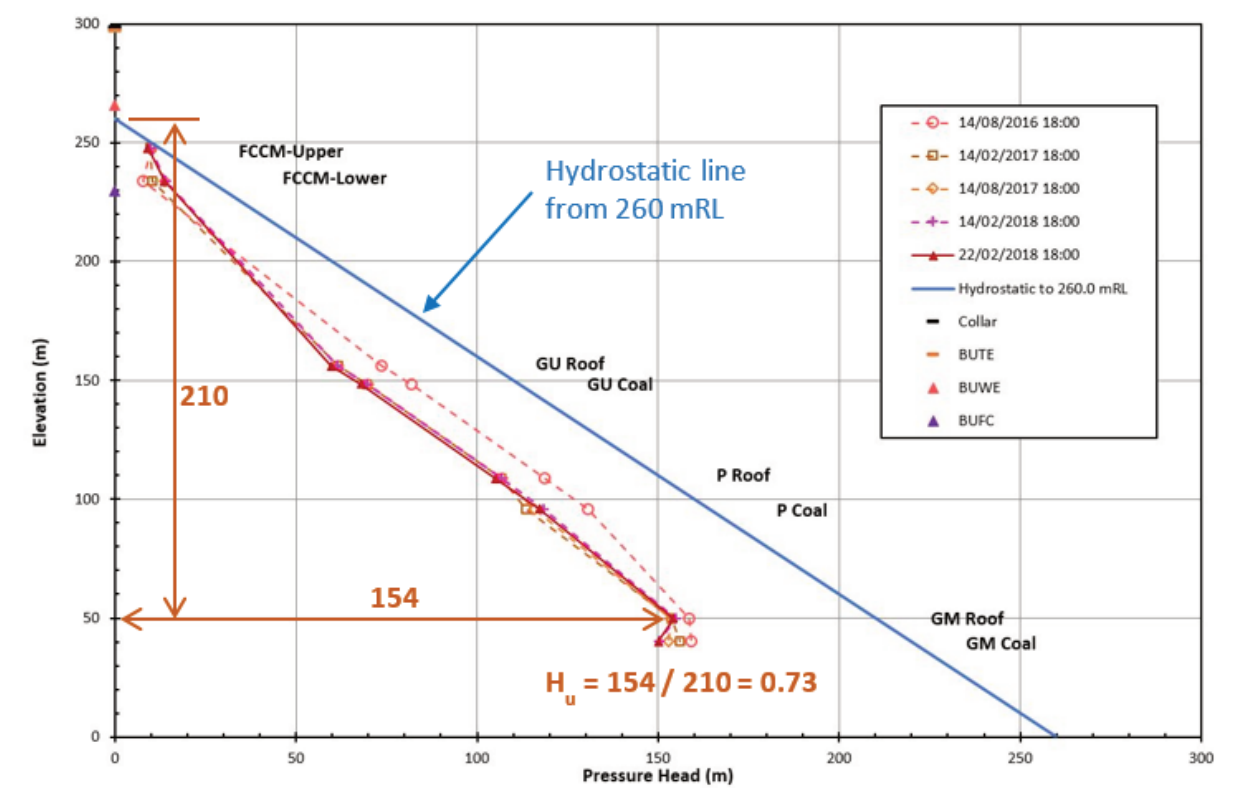

Figure 12 Determination of Hu at a point using piezometer data (after Simmons 2019), annotations refer to stratigraphic locations of vibrating wire piezometer sensors installed in a borehole

Direct modelling of groundwater pressures using finite element analysis is available as part of modern slope stability analysis tools. While values of $\mathrm{H}_{\mathrm{u}}$ can be extracted from a finite element flow model together with the phreatic surface, it is unnecessary as the modelled groundwater pressures can be directly used in stability analysis. Finite element groundwater flow analysis requires specification of hydraulic conductivities and also 
of representative boundary conditions. In the absence of site-specific data, Table 6 provides typical hydraulic conductivity parameters that may be useful as a starting point for modelling groundwater pressures.

Table 6 Nominal permeability parameters for sub- and bituminous coal mines (Simmons, pers. files)

\begin{tabular}{llllll}
\hline Material & $\begin{array}{l}\text { Uniaxial compressive } \\
\text { strength (MPa) }\end{array}$ & $\mathbf{k 1}\left(\mathbf{m s}^{-\mathbf{1}}\right)$ & $\mathbf{k 2} \mathbf{k} \mathbf{1}$ & $\boldsymbol{\alpha}(\mathbf{d e g})$ & $\mathbf{H}_{\mathbf{u}}$ \\
\hline Weathered non-coal & $0.5-3$ & $2 \times 10^{-6}$ & 0.50 & Strata & $0.85-0.95$ \\
Fresh non-coal & $3-25$ & $2 \times 10^{-8}$ & 0.25 & Strata & $0.70-0.95$ \\
Weathered coal & $1-3$ & $2 \times 10^{-6}$ & 1.00 & Strata & $0.80-0.95$ \\
Fresh coal & $5-15$ & $2 \times 10^{-7}$ & 0.75 & Strata & $0.70-0.90$ \\
\hline
\end{tabular}

Note: $\mathrm{k} 1$ parallel to bedding, $\mathrm{k} 2$ perpendicular to bedding

The tabulated hydraulic conductivities are anisotropic, with the degree of anisotropy dependent on the relative roles and nature of material flow and fracture flow. The tabulated values are the same for different coal measures ranks. This is a consequence of many factors ranging from ignorance through lack of measurements to compensating effects related to grain and fracture porosity interactions for materials of different ranks. It should also be noted that the flow anisotropy is directional, being specifically linked to the orientation of the coal measures rock bedding. In folded rock masses this provides significant challenges for representative modelling. Tabulated $\mathrm{H}_{\mathrm{u}}$ values are provided for guidance, as a simplifying alternative to finite element modelling when commencing slope stability analysis.

\subsection{Gas desorption and outburst}

The nature of coal materials also means that adsorbed and dissolved gases are present within coal measures rocks. Gases may exsolve when groundwater pressure is reduced and may desorb when total stress on carbonaceous material is reduced both by physical unloading (excavation) and by pore pressure reduction. The volumes of gas may be significant and the release of gas may occur suddenly and rapidly.

Within the underground coal mining community, it is well known that violent ground instability may result particularly in highly fractured coal adjacent to fault zones, where the greater degree of fracturing provides a combination of greater surface area and reduced rock mass strength. The outburst mechanism is not fully understood and is the subject of ongoing research. It is necessary for open cut geotechnical practitioners to be aware of the mechanism of outburst, because rare instances of excavated face instability have been reported in circumstances where outburst is the only rational explanation.

\subsection{Waste dump materials}

Waste dumps, most commonly called spoil dumps in the black coal mining industry, should be considered as structured soil-like materials. In practice, particle sizes range from boulders to clays. The systematic arrangement of benches and dumping methods results in segregated layers locally inclined at the rill angle. Contrary to some soil mechanics textbook statements and persistent common belief, the rill angle is a function of particle dynamics during placement and bears almost no relationship to the angle of internal friction measured in shear tests (Metcalf 1966). The segregated small-scale structure, complex larger-scale layering, and range of waste materials that may be comingled present a challenge for geotechnical characterisation. Spoil dumps are also very large, and the consequence of instability can be extremely high.

A framework for rationally assessing shear strength of spoil masses was developed within the BHP mines of the Bowen Basin. This was based on categorising all spoils based on geological attributes and understanding that the shear strengths of saturated and remoulded spoil zones were significantly lower than for the predominantly unsaturated zones within spoil dumps. The categorisation process was formalised by Simmons \& McManus (2004). Several questions about the categorisation process and development of a facility for testing larger spoil samples at stress levels corresponding to very high dumps lead to significant revisions of the spoil categorisation process (Simmons \& Fityus 2016). Shear strengths for all common spoil 
materials are listed in these references and are not repeated in this paper. Many other complex geotechnical considerations for large dump design are described in Hawley \& Cunning 2017.

Placement of MPR within spoil dumps has created a new class of geotechnical modelling challenges because of the combination of geometric complexity and time-dependent moisture transfer between initially unsaturated spoil and saturated MPR. Desaturation and drying-back of MPR results in the material strength behaviour transitioning from short-term undrained fines dominated response to long-term friction dominated response (Koosmen et al. 2015). Typical drained friction angles $\phi^{\prime}$ for CPR and MPR are in the range of 33 to $36^{\circ}$, with apparent effective cohesion intercepts of 5 to $25 \mathrm{kPa}$. Geotechnical practitioners should exercise skill and judgement regarding selection of material zones and geotechnical strength models for dumps including MPR, and assist operational personnel with development of successful safe placement methodologies that control instability risks resulting from short-term strength behaviour prior to consolidation and drainage of initially wet-semi-liquid MPR.

Significant uncertainties remain regarding stability of spoil dumps. The currently accepted norm for dump design is a maximum $5 \mathrm{~m}$ depth of saturation where a phreatic surface and reduced, saturated strengths apply. Circumstantial evidence supporting this norm is currently the subject of ongoing research and measurement using piezometers. Dump heights in excess of $300 \mathrm{~m}$ and zones of relatively moist spoil may result in mechanical saturation, where the stabilising effects of unsaturated suctions are minimised. Dump stability design for very high structures must include sensitivity analyses that consider much greater than usual saturated thicknesses and deeper phreatic surfaces.

\section{$7 \quad$ Brown coal geotechnical models and parameters}

\subsection{Shear strength}

A very widespread body of geotechnical knowledge for the Latrobe Valley brown coal mines developed during the formative decades of large-scale mining. Much of this knowledge remains in-house with mining operators and consulting organisations. Shear strength for lignite will vary depending on the density of the material skeleton as well as the nature and distribution of the organic component. Shear strength for interseam and overburden materials is also variable but amenable to conventional geotechnical investigation and testing.

In the absence of site-specific information, material parameters may be sourced from Trollope et al (1965), Srithar \& Ervin (2007), Sullivan (2008), Seddon (2013), Moein et al. (2016), and Waghorne \& Disfani (2019). Table 7 is a simplified summary of key parameters extracted from the above sources. Very similar material parameters have been recorded for lignite deposits of similar geological age and rank elsewhere (Kavvadas et al. 1994, 2013). Inevitably, slope stability considerations are governed by groundwater pressure distribution within and below jointed lignite, and the residual shear strength of weak interseam clays.

Table 7 Nominal shear strength parameters for Latrobe Valley brown coal mines (Simmons, pers. files)

\begin{tabular}{llll}
\hline Material & $\gamma\left(\mathbf{k N m}^{-3}\right)$ & $\mathbf{c}^{\prime}(\mathbf{k P a})$ & $\phi^{\prime}(\mathbf{d e g})$ \\
\hline Overburden and non-coal interburdens & $17-29$ & $0-40$ & $18-35$ \\
Lignite & $10-12$ & $150-350$ & $35-45$ \\
Interseam clay (residual) & $17-19$ & $0-10$ & $10-18$ \\
Shearing of coal joint & - & 0 & $30-40$ \\
Overburden and interburden waste & $17-19$ & $0-10$ & $22-28$ \\
Settled ash & $13-14$ & $0-10$ & $28-32$ \\
\hline
\end{tabular}

\subsection{Deformability}

In some contrast to the situation for shear strength, there is a comparative lack of publicly accessible information regarding deformation parameters for the Latrobe Valley brown coal mines. This is somewhat surprising, given the very large and long-term body of information on subsidence and slope movements that 
exists and continues to be collected. Table 8 lists representative Young's modulus $E$ and Poisson's ratio $v$ together with mass tensile strength ( $t$ ) parameters assembled by the author from the same sources as listed for shear strength above and checked against a wide body of in-house and confidential project information that cannot be publicly disclosed. In the absence of better and more site-specific information, this tabulation should provide a useful starting point.

Table 8 Nominal deformability parameters for Latrobe Valley brown coal mines (Simmons, pers. files)

\begin{tabular}{llll}
\hline Material & $\mathbf{E}(\mathbf{M P a})$ & $\mathbf{v}$ & $\mathbf{t}(\mathbf{M P a})$ \\
\hline Overburden and non-coal interburdens & $50-100$ & $0.3-0.4$ & $5-20$ \\
Lignite & $400-800$ & $0.3-0.4$ & $30-50$ \\
Interseam clay & $50-100$ & $0.3-0.4$ & $5-20$ \\
Overburden and interburden waste & $25-100$ & $0.3-0.4$ & $0-10$ \\
Settled ash & $10-50$ & $0.40-0.45$ & $0-20$ \\
\hline
\end{tabular}

\subsection{Degradation and weathering}

Brown coal degrades after atmospheric exposure, forming a dark patina with fine shrinkage cracks and eventually crumbling to an erodible sandy silt. The formation of sinkholes resulting from degradation and erosion of large-scale vertical joints is a recognised geotechnical hazard due to the infrastructure bounding the mining field. Sinkhole formation is expected to continue to be manifested after completion of mining (Department of Jobs Precincts and Regions 2019).

Exposed overburden and interburden sediments are also subjected to ongoing degradation and weathering processes typical for hard cohesive soils and dense cohesionless soils. Overburden clays may include indurated zones that are widespread in Australian Palaeogene and Neogene sediments and that result from mild cementation processes associated with warmer and wetter palaeoclimates.

\subsection{Hydraulic conductivity}

The history of Latrobe Valley mining is closely linked with the management of large-scale aquifer depressurisation. Likewise, reservoir production studies from the laterally equivalent Gippsland Basin petroleum resource fields have resulted in detailed knowledge of aquifer and aquiclude units and large-scale groundwater model development and fine-tuning.

Such information is large-scale and therefore of limited value for fine-scale geotechnical assessment of brown coal pit slope and floor stability. Despite the widespread installation of piezometers, there is very little published information on slope-scale and geological unit-specific hydraulic conductivity that is directly relevant for geotechnical practice. Table 9 is a summary prepared by the author based on published information (see shear strength earlier) which is intended to provide a starting point for geotechnical practitioners in the absence of better and more site-specific information.

Table 9 Nominal PERMEABILITY PARAMETERS for Latrobe Valley brown coal mines (Simmons, pers. files)

\begin{tabular}{lllll}
\hline Material & $\mathbf{k 1}\left(\mathbf{m s}^{-1}\right)$ & $\mathbf{k 2} / \mathbf{k} \mathbf{1}$ & $\boldsymbol{\alpha}(\mathbf{d e g})$ & $\mathbf{H}_{\mathbf{u}}$ \\
\hline Overburden and non-coal interburden aquifers & $2 \times 10^{-6}$ & 0.25 & Strata & $0.80-0.95$ \\
Lignite & $2 \times 10^{-7}$ & 0.50 & Strata & $0.70-0.95$ \\
Interseam clay & $2 \times 10^{-8}$ & 0.25 & Strata & $0.70-0.90$ \\
Overburden and interburden waste & $2 \times 10^{-5}$ & 0.50 & Strata & $0.90-1.00$ \\
Settled ash & $2 \times 10^{-7}$ & 0.25 & Strata & $0.80-1.00$ \\
\hline
\end{tabular}

Note: $\mathrm{k} 1$ parallel to bedding, $\mathrm{k} 2$ perpendicular to bedding 


\subsection{Gas desorption and outburst}

To the author's knowledge, gas desorption has not been a significant concern for brown coal mining, probably because of the large-scale of pit exposures and the widespread practice of providing lateral drainage holes for groundwater depressurisation purposes. Likewise, there is no record of gas outburst hazards and the lateral drainage holes would assist in maintaining this situation.

\subsection{Waste dump materials}

Overburden quantities in the Latrobe Valley mines are relatively modest in comparison to black coal mines. Weight balance (Department of Jobs Precincts and Regions 2019) is a critical geotechnical control for managing pit floor heave and pit slope hazards, and waste materials are typically dumped to optimise stability and focus depressurisation treatments on active mining areas. Geotechnical characterisation of waste dump materials has been described in some detail for the Morwell River Diversion project (Srithar \& Ervin 2007; Seddon 2013).

\section{$8 \quad$ Analytical tools}

\subsection{Defect data collection and interpretation}

Methodologies for mapping rock mass defects have changed dramatically with the advent of UAV-based real-time imagery analysis and the retirement of geologists' compasses. Geophysical tools can capture and interpret defect intersections within boreholes. No methodology can escape the limitations of spatial bias, retrospectivity, and over-simplification of using stereonets to represent spatially separated defects. During the author's career, there has been remarkably little advancement in mapping the different forms of intersection of defects, despite this being the key to the development of structurally controlled or composite instability mechanisms. This begs the question of whether many geotechnical practitioners give sufficient thought to mapping.

In coal measures strata, it is common to observe two mutually orthogonal defect sets to bedding surfaces, and for the continuity and persistence of across-bedding defects to be related to spacing. This phenomenon is due to erosional unloading that triggers extension strain fracturing and has been modelled numerically (Stefanizzi et al. 2007). Additional defect sets are generally induced by tectonic processes with their relative orientations typically related to faulting. Relative orientations of tectonic structures provide direct evidence of the direction and nature of fault processes and predictive capability for future pit slope exposures. The connections among persistence, spacing, block dimension, and rock mass response to excavation are critical to the performance of a slope excavated in structured rock, but interpretation is rarely attempted by geotechnical practitioners and not available within defect mapping software packages.

\subsection{Slope stability analysis}

Rock mass structure-controlled stability analysis follows a well-worn path of defect data collection, simplifying assumptions to render a problem amenable to analysis, and application of kinematic analysis procedures. The limitations of analysis based on stereonet principles are discussed above, but the principles are sound and methodologies exist for combining orientation data with slope observations (McQuillan et al. 2018) to formulate likelihoods of mechanism development.

Two methodologies for strength-controlled slope stability analysis are now in widespread use by practitioners, predominantly in 2D applications but with more recent uptake of 3D applications. Limit equilibrium analysis to generate FOS outcomes is still by far the most widely used, but increasing use is being made of deformation analysis to generate strength reduction factor (SRF) outcomes. SRF-based stability assessment requires care and skill in deformation modelling. When there is considerable model uncertainty, consideration should be given to checking SRF outcomes against FOS outcomes, for which there is a longer 
history of experienced engineering judgement. The same consideration applies to checking 3D outcomes against 2D outcomes, where possible.

\subsection{Deformation analysis}

Methodologies for deformation analysis may be subdivided into two formats: continuum-based, such as finite element or finite difference modelling, and discontinuum-based distinct element modelling. Each format has advantages and limitations, and the current proliferation of different modelling systems attests to a very wide range of modelling demands for which specific formulations have been developed, as well as a competitive market for modelling services.

Both 2D and 3D modelling capabilities are currently available to geotechnical practitioners. 3D offers the opportunity to account for a more realistic representation of complex geology and pit dimensions. Practical modelling resource constraints limit the resolution of 3D models, resulting in complex and finer-scale details being more amenable to $2 \mathrm{D}$ modelling.

Irrespective of the modelling methodology, representative modelling requires careful specification of geotechnical model parameters based on some combination of available data, field observations, and peer-reviewed precedent modelling. Equally significant are consideration of representative stress paths and specification of appropriate boundary conditions. While these details are often the realm of specialist analysts and consultants, practitioners should take the time and trouble to understand the basis for modelling before accepting outcomes and making design decisions.

\subsection{Groundwater pressure and seepage analysis}

Similar comments apply to groundwater and seepage modelling as to deformation modelling, with the proviso that there is generally less information available for ground-truthing a seepage model and often less background capability among geotechnical practitioners for understanding how groundwater modelling at slope-scale actually works.

\section{$9 \quad$ Post-mining landforms}

The coal mining industry is required to provide an acceptable standard of environmental management, but the intended use and future value of post-mining landforms still a matter of industry and societal debate.

For Australian black coal mines, re-shaped slopes comprising some combination of blasted rock or dumped spoil are usually designed to be relatively flat for erosion control and land use purposes, and slope stability can readily be assessed using a soil mechanics infinite-slope or sliding shallow slab approach (Duncan \& Wright 2005). Steep excavated rock slopes left as post-mining landforms may require slope stability assessment using rock mechanics principles (Wylie \& Mah 2004). An approach to assessing long-term geotechnical stability of post-mining voids for planning purposes has been proposed based on observations of voids where mining operations have either ceased or been suspended for some period of time (Henderson \& Merritt 2015).

Tailings storage facilities (the industry avoids the term 'dams' as facilities include backfilling of mined-out voids) require capping to encapsulate tailings sediment and minimise leaching and transport of tailingscontacted groundwater. Crusted surfaces on facilities are usually of limited thickness, typically 1 to $3 \mathrm{~m}$, with underlying tailings remaining soft and normally consolidated with near-surface short-term strength $\left(\mathrm{s}_{\mathrm{u}}\right)$ ranging from 5 to $30 \mathrm{kPa}$ depending on the history of crust development. Design of capping systems is based either on minimum-displacement or managed-displacement methods, requiring careful geotechnical assessment and design including realistic models for machine loadings. Capping thicknesses are generally limited to the minimum that complies with regulatory requirements. Capping loads induce consolidation settlements that occur over years to decades because of the low hydraulic conductivity and large drainage path length for typical tailings deposits. 
Options for post-mining landforms for Australian brown coal mines may be more limited because of the modest volumes of waste available and the key requirement to achieve weight balance to eliminate the risks of floor heave and related slope instability (Department of Jobs Precincts and Regions 2019). Residual void lakes provide a mechanism to achieve stability but obviously require large volumes of water and must be matched with predictions of future groundwater pressure scenarios. Waghorne \& Disfani (2019) discuss potential rebound responses to aquifer re-pressurisation over significant time periods.

Both soil and rock slope stability principles apply to relatively short timescales, typically a few decades of observational experience at most. All long-term post-mining slopes are subjected to soilscape and landscape evolution processes (Willgoose 2018) for which modelling requires a different approach (Telluric Research 2020). At the time of preparing this paper, the mining industry typically separates geotechnical roles for slope stability from environmental roles for post-mining landscape rehabilitation. There is much for both disciplines to gain from close collaboration regarding post-mining landform design.

\section{Acknowledgement}

This paper presents personal perspectives. These have evolved over decades of interactions and shared experiences with many geotechnical, mining, and environmental professionals in both practice and academia. For this, I will always be humbled and appreciative. I remain particularly grateful to Murray Harris, Dan Eisenstein, Stan Thompson, Dave Cruden, Nordie Morgenstern, Bryan Watts, Hugh Trollope, Kevin Rosengren, Dennis McManus, Stephen Fityus, and Paul Maconochie for their influences in shaping my perspectives. I am also grateful to Matt Tsang for stimulating discussions about his current SRM-based rock mass shear strength research and willingness to provide examples.

\section{References}

Australian Groundwater and Environmental Consultants Pty Ltd 2017, Report on Project China Stone Additional Information on Groundwater: For MacMines Austasia Pty Ltd, viewed 3 March 2020, http://eisdocs.dsdip.qld.gov.au/ China\%20Stone\%20Coal/AEIS/Additional\%20Information\%20to\%20the\%20EIS\%20-\%20Volume\%206/attachment-dadditional-information-on-groundwater.pdf

Beale, G \& Read, J 2013, Guidelines for Evaluating Water in Pit Slope Stability, CSIRO Publishing, Collingwood.

Beamish, B, Edwards, D \& Theiler, J 2015, 'Case study of an opencut coal mine self-heating event benchmarked against a new laboratory test method', in JW Beeston (ed.), Proceedings of the Bowen Basin Symposium, Coal Geology Group and The Bowen Basin Geologists Group, Brisbane, pp. 13-21.

Bioregional Assessments 2018, Hydrogeology and groundwater quality. Australian Government, viewed 20 January 2020, https://www.bioregionalassessments.gov.au/assessments/11-context-statement-gippsland-basin-bioregion/114hydrogeology-and-groundwater-quality

Currell, MJ, Werner, AD, McGrath, C, Webb, JA \& Berkman, M 2017, 'Problems with the application of hydrogeological science to regulation of Australian mining projects: Carmichael Mine and Doongmabulla Springs', Journal of Hydrology, vol. 548, pp. 674-682, http://dx.doi.org/10.1016/j.hydrol.2017.03.031

Department of Jobs Precincts and Regions 2019, Latrobe Valley Regional Rehabilitation Strategy Regional Geotechnical Study Synopsis Report, viewed 4 March 2020, https://earthresources.vic.gov.au/_data/assets/pdf_file/495323/12639_DJPR_LatrobeValley-Regional-Rehabilitation-Strategy-Geotechnical-Study-Synopsis_V9.pdf

Duncan, JM \& Wright, SG 2005, Soil Strength and Slope Stability, John Wiley \& Sons Inc., Hoboken.

Fityus, SG, Jeffery, M, Aglias, KJ, Johnston, JA \& Simmons, JV 2015, 'Weathering and degradation of shales and mudrocks', Proceedings of the 13th International Congress on Rock Mechanics, Canadian Institute of Mining, Metallurgy \& Petroleum, Toronto.

Geoscience Australia 2013, Australia's Mineral Resource Assessment 2013, Australian Government, viewed 23 January 2020 , https://www.ga.gov.au/data-pubs/data-and-publications-search/publications/australian-minerals-resource-assessment

GNS Science 2020, Coal Formation, viewed 5 February 2020, https://www.gns.cri.nz/Home/Learning/Science-Topics/FossilEnergy/Creating-Hydrocarbons/Coal-Formation

Green, DR 2015, Coallog Geology and Geotechnical Training Manual, ACARP Project C22017, viewed 3 March 2020, https://ausim.com/coal-log/

Hawley, M \& Cunning, J 2017, Guidelines for Mine Waste Dump and Stockpile Design, CSIRO Publishing, Collingwood.

Hazelwood Mine Fire Inquiry 2016, Hazelwood Mine Fire Inquiry 2015/2016 Volume IV Mine Rehabilitation, Department of Economic Development, Jobs Transport and Resources, viewed 26 February 2020, https://www.parliament.vic.gov.au/ file_uploads/11172_HAZ_MFIReport-2015_16-Volume4_FA_LR_15B0_pQfGZRfC.pdf

Henderson, S \& Merritt, J 2015, 'A framework for void stability assessment within mine closure planning', in JW Beeston (ed.), Proceedings of the Bowen Basin Symposium, Coal Geology Group and The Bowen Basin Geologists Group, Brisbane, pp. 463-471. 
Hillis, RR, Enever, JR \& Reynolds, SD 1999, 'In situ stress field of eastern Australia', Australian Journal of Earth Sciences, vol. 46, pp. 813-825.

Hoek, E \& Brown, ET 2018, 'The Hoek-Brown failure criterion and GSI - 2018 edition', Journal of Rock Mechanics and Geotechnical Engineering, vol. 11, issue 3, pp. 445-463, https://doi.org/10.1016/j.jrmge.2018.08.001

Holdgate, GR 2003, 'Coal, world class energy reserves without limits', in WD Birch (ed.), Geology of Victoria, Special Publication 23, Geological Society of Australia, pp. 489-518.

Holdgate, GR 2005, 'Geological processes that control lateral and vertical variability in coal seam moisture contents-Latrobe Valley (Gippsland Basin) Australia', International Journal of Coal Geology, vol. 63, pp. 130-155.

Holtz, RD \& Kovacs, WD 1981, An Introduction to Geotechnical Engineering, Prentice-Hall, Upper Saddle River.

Kavvadas, M, Papadopoulos, B \& Kaltezoitis, N 1994, 'Geotechnical properties of the Ptolemais lignite', Geotechnical and Geological Engineering, vol. 12, no. 87, https://doi.org/10.1007/BF00429768

Kavvadas, M, Agiotantis, Z, Schilizzi, P \& Steiakakis, C 2013, 'Stability and movements of open-pit lignite mines in Northern Greece', Proceedings of the 18th International Conference on Soil Mechanics and Foundation Engineering, International Society for Soil Mechanics and Geotechnical Engineering, London, pp. 2193-2196.

Koosmen, K, Simmons, J \& Fityus, S 2015, 'Considerations for the design of spoil piles containing co-disposed washery wastes', in JW Beeston (ed.), Proceedings of the Bowen Basin Symposium, Coal Geology Group and The Bowen Basin Geologists Group, Brisbane, pp. 371-382.

Mackie, CD 2009, Hydrogeological Characterisation of Coal Measures and Overview of Impacts of Coal Mining on Groundwater Systems in the Upper Hunter Valley of NSW, PhD Thesis, University of Technology Sydney, Sydney.

Mackie Environmental Research 2009, Groundwater management studies ravensworth operations project, Report to Ravensworth Operations Pty Limited, viewed 3 March 2020, https://www.ravensworthoperations.com.au/en/publications/EA/ Appendix_9_Groundwater_Part-A_MainText.pdf

Martin, D \& Stacey, P 2018, Guidelines for Open Pit Slope Design in Weak Rocks, CSIRO Publishing, Collingwood.

McQuillan, A, Canbulat, I, Payne, D \& Oh, J 2018, 'New risk assessment methodology for coal mine excavated slopes', International Journal of Mining Science and Technology, vol. 28, pp. 583-592, https://doi.org/10.1016/j.ijmst.2018.07.001

Medhurst, TP \& Brown, ET 1998, 'A study of the mechanical behaviour of coal for pillar design', International Journal of Rock Mechanics and Mining Science, vol. 35, no. 8, pp. 1087-1105.

Metcalf, JR 1966, 'Angle of repose and internal friction', International Journal of Rock Mechanics and Mining Sciences, vol. 3, pp. 155-161.

Moein, F, Xue, J, Dent, B \& Mackay, R 2016, 'Review of the historical data characterizing Latrobe Valley brown coal consolidation behaviour', in M Eggers, JS Griffiths, S Parry \& MG Culshaw (eds), Developments in Engineering Geology. Engineering Geology Special Publication 27, The Geological Society, London, pp. 217-226, http://doi.org/10.1144/EGSP27.19

Rajabi, M, Tingay, M, Heidbach, O, Hillis, R \& Reynolds, S 2017, 'The present-day stress field of Australia', Earth-Science Reviews, vol. 168, pp. 165-189, https://dx.doi.org/10.1016/j.earscirev.2017.04.003

Raymond, OL 2012, Surface Geology of Australia 1:1M Data Set, A3 map image, Geoscience Australia, viewed 5 February 2020, https://ecat.ga.gov.au/geonetwork/srv/eng/catalog.search\#/metadata/73360

Seddon, K 2013, Review of Failure of Morwell River Diversion Yallourn, ATC Williams Report Ref.112179.01R01 to Department of Primary Industries, Victoria, http://www.energyandresources.vic.gov.au/earth-resources/information-for-community-andlandholders/mining-and-extractives/latrobe-valley-coal-mines/regulatory-reviews/yallourn-coal-mine-inquiries/review-offailure-of-morwell-river-diversion

Selley, RC 1996, Ancient Sedimentary Environments, 4th edn, Chapman \& Hall, London.

Sherwood Geotechnical and Research Services 2011, ESFC-Based Trigger Levels for Monitoring Pit Wall Stability, Report Number 7260-1-2, Australian Coal Association Research Program.

Simmons, JV \& McManus, DA 2004, 'Shear strength framework for design of dumped spoil slopes for open pit coal mines', in RJ Jardine, DM Potts \& KG Higgins (eds), Advances in Geotechnical Engineering The Skempton Conference, London, pp. 981-991.

Simmons, JV 2013, 'Geotechnical support for open pit coal mining', Australian Geomechanics, vol. 48, no. 1, pp. 85-100.

Simmons, JV \& Fityus, SG 2016, The Stability of Very High Spoil Piles, Report for ACARP Project C20019, Australian Coal Association Research Program.

Simmons, JV \& Yarkosky, RR 2017, 'Dragline Spoils', in PM Hawley \& J Cunning (eds), Guidelines for Mine Waste Dump and Stockpile Design, CSIRO Publishing, Clayton, pp. 233-258.

Simmons, J, Ebeling, P \& Stacey, P 2018, 'Weak Sedimentary Coal, Chalk and Limestone', D Martin \& P Stacey (eds), Guidelines for Open Pit Slope Design in Weak Rocks, CSIRO Publishing, Clayton, pp. 203-232.

Simmons, JV 2019, 'Implications of groundwater pressure models for slope stability assessment', in HE Acosta-Martinez \& BM Lehane (eds), Proceedings of the 13th Australia New Zealand Conference on Geomechanics, Australian Geomechanics Society, St Ives, pp. 505-510.

Sirevaag, H, Ksienzyk, A K, Jacobs, J, Dunkl, I \& Laufer, A 2018, 'Tectono-thermal evolution and morphodynamics of the Central Dronning Maud Land Mountains, East Antarctica, based on new thermochronological data', Geosciences, vol. 8, issue 11, https://doi.org/10.3390/geosciences 8110390

Smerdon, BD \& Ransley, TR 2012, Water Resource Assessment for the Surat Region, Report to the Australian Government from the CSIRO Great Artesian Basin Water Resource Assessment, https://publications.csiro.au/rpr/ download?pid=csiro:EP132644\&dsid=DS4 
Srithar, S \& Ervin, M 2007, 'River diversion over a backfilled open cut brown coal mine', in J Ameratunga, B Taylor \& M Patten (eds), Proceedings of the 10th Australia New Zealand Conference on Geomechanics, Australian Geomechanics Society and the New Zealand Geotechnical Society Inc., St Ives, pp. 306-311.

Standards Australia 2017, Geotechnical site investigations AS1726:2017, Standards Australia.

Standards Australia 1987, Classification and Coding Systems for Australian Coals A2096:1987, Standards Australia.

Stefanizzi, S, Barla, G \& Kaiser, PK 2007, 'Numerical modelling of strain driven fractures around tunnels in layered rock masses', in L Ribeira de Souza, C Olalla \& N Grossman (eds), Proceedings 11th International Congress on Rock Mechanics, Taylor \& Francis, Lisbon, pp. 971-974.

Sullivan, T 2008, Mining Warden Report Yallourn Mine Batter Failure Inquiry, Victorian Government Printer, https://www.parliament.vic.gov.au/papers/govpub/VPARL2006-10No156.pdf

Telluric Research 2020, SIBERIA/EAMS, version 8.33, computer software, https://www.telluricresearch.com/siberia-homepage.html Trollope, DH, Rosengren, KJ \& Brown, ET 1965, 'The mechanics of brown coal', Geotechnique, vol. 15, no. 4, pp. 363-386.

Waghorne, EP 2009, 'Brown coal mining in the Latrobe Valley', Monograph 12 Australasian Coal Mine Practice, 3rd edn, The Australasian Institute of Mining and Metallurgy, Carlton, pp 470-485.

Waghorne, EP \& Disfani, MM 2019, 'Land subsidence/rebound change after Hazelwood mine rehabilitation', in AB Fourie \& M Tibbett (eds), Proceedings of the 13th International Conference on Mine Closure, Centre for Geomechanics, Perth, pp. 111-121, https://doi.org/10.36487/ACG_rep/1915_10_Waghorne

Willgoose, G 2018, Principles of Soilscape and Landscape Evolution, Cambridge University Press, Cambridge, 324 p.

Wylie, DC \& Mah, CW 2004, Rock Slope Engineering, Civil and Mining, 4th edn, Spon Press, London 431 p. 